DOI: 10.1590/permusi2015a3110

\title{
As pesquisas históricas na interpretação de Chopin
}

\author{
Nahim Marun (Instituto de Artes UNESP, São Paulo, SP) \\ nmarun@uol.com.br
}

\begin{abstract}
Resumo: As pesquisas sobre performance historicamente informada se concentraram inicialmente em obras do século XVII e XVIII, trazendo novas ideias aos processos analíticos tradicionais e impulsionando novas abordagens interpretativas desses estilos. Entretanto, ao invés de apontar resultados unívocos e precisos, tais estudos multiplicaram as possibilidades de releituras musicais e originaram as mais diversas vertentes interpretativas. As investigações aportaram, pouco à pouco, aos estilos musicais que se sucederam ao barroco e ao clássico, chegando ao século XIX. Neste artigo, trataremos de alguns dilemas interpretativos decorrentes da diversidade editorial na música para piano de Frédéric Chopin (1810-1849). A ampla divulgação das suas primeiras edições na internet, juntamente com as possibilidades de performance trazidas pelas pesquisas históricas, expandiram as referências estabelecidas para sua música e trouxeram mais flexibilidade interpretativa a alguns parâmetros musicais, como direções fraseológicas, escolhas das articulações, timbre instrumental, dedilhados, pedais, rubati e ornamentações.
\end{abstract}

Palavras-chave: processos editoriais em Frédéric Chopin; performance historicamente informada do período romântico; interpretação pianística contemporânea.

\section{The historical researches on Chopin's performance}

\begin{abstract}
The researches on historically informed performance were, at first, focused on seventeenth- and eighteenth- century works; hence they brought new thoughts on traditional analytical procedures, and also stimulated new performances of these styles. However, instead of pointing unambiguous and precise results, such studies have multiplied the possibilities of musical interpretation. The researches on these subjects have reached, little by little, to the domains of other musical styles. In this article, we shall deal with some performance issues brought by the number of music editions on Frédéric Chopin (1810-1849). The unrestricted access to the first editions at internet, altogether with the possibilities brought by historical approaches have expanded the established guidelines for his music and have brought more flexibility to some topics of their performance practice, such as phrase structuring, touches, tone, fingering, pedaling, rubati and ornamentations.
\end{abstract}

Keywords: editorial procedures in Frédéric Chopin; romanticism's historical informed performance; contemporary piano performance.

\section{1 - Os instrumentos de época}

O jornal norte-americano International Herald Tribune, vinculado ao New York Times, informou na edição de 11 de julho de 2010 que as cidades de Paris, Varsóvia e Pequim foram as cidades que mais festejaram o bicentenário de nascimento de Frédéric Chopin. A Cité de la Musique e a Salle Pleyel, duas prestigiosas salas de concertos de Paris, comemoraram a efeméride incluindo nas suas programações o ciclo integral da obra de Chopin para piano solo, entre os dias 21 de março e 06 de junho de 2010. O principal diferencial dessa maratona musical foi o emprego, em todas as apresentações, de pianos autênticos do século XIX fabricados pela Maison Pleyel, a marca preferida do compositor polonês. Vários intérpretes representativos da atualidade participaram: Abdel Rahman el Bacha, Dang Thai Son, Pierre Goy, Edna Stern, Vanessa Wagner, Nelson Goerner, Kevin Kenner, entre outros. 
$\mathrm{Na}$ ocasião, foram divulgados vários registros que adotaram linhas de pesquisa relacionadas à performance historicamente informada, à exemplo do pianista Alain Planes: Chopin Chez Pleyel, pelo selo Harmonia Mundi, 2009. Segundo informações do libreto do CD, além de empregar um instrumento Pleyel de 1836, o intérprete reproduziu exatamente a ordem e as obras de um recital realizado pelo próprio compositor e estudou em detalhes, vários tratados sobre a técnica chopiniana, objetivando revelar uma abordagem diferenciada do uso dos rubati e dos ornamentos.

Em 1999, o selo Sony lançou os dois concertos para piano e orquestra do compositor, com o pianista Emanuel Ax e Sir Charles Mackerras frente à Orchestra of the Age of Enlightenment. O solista utilizou-se de um instrumento fabricado pela Maison Erard, a principal concorrente da Maison Pleyel, no século XIX.

Outro exemplo dessa tendência surgiu na "Oitava Competição Internacional para Jovens Pianistas Chopin Golden Ring", que apresentou em seu edital uma nova categoria para a performance historicamente informada. As provas deste grupo foram executadas em um piano histórico And Wittenz e se realizaram em outubro dos anos de 2012 e 2013, na Eslovênia.

A reconhecida opção de Chopin pelos instrumentos Pleyel, "apontava para algo muito evidente: a resistência ao mecanismo de escape duplo." (CHIANTORE, 2001, p.308). Tanto Ignaz Pleyel (1750-1819) quanto seu filho, Joseph Etienne Camille Pleyel (17881855), fabricavam seus pianos com mecanismo de escape simples, que possibilitavam a obtenção de uma sonoridade ressonante, doce e transparente. Os Pleyel incorporaram as mudanças mecânicas aos seus pianos em um ritmo bem mais lento que as demais marcas europeias. Ainda sobre a predileção quanto aos mecanismos e sonoridades destes pianos, é interessante lembrar a declaração que Chopin fez a Liszt (HINSON, 1985, p.180): "quando eu estou indisposto, eu toco em um piano Erard, pois nele o timbre é pré-fabricado; mas quando estou suficientemente disposto e forte para procurar meu próprio timbre, eu preciso de um Pleyel".

Chopin tocou pouco para o grande público e as poucas dezenas de apresentações do compositor se limitaram a soirées privadas, em salões de dimensões reduzidas, onde não era absolutamente necessário um instrumento com grande amplitude sonora. De acordo com o aluno e assistente de Chopin, Karol Mikuli, "Chopin tocava com toque delicado, evitando acentos fortes e estridentes [...] mas seu toque era naturalmente profundo e ressonante." (EIGELDINGER, 1986, p.56).

O intuito das gravações que se utilizam dos instrumentos históricos como Pleyel e Erard não é o de substituir ou suplantar as gravações disponíveis no mercado fonográfico, mas sim, o de estimular a imaginação do intérprete para novas possibilidades criativas, como timbres pianísticos e sonoridades. Assim sendo, os conceitos estéticos e interpretativos do romantismo se reescrevem, aportando novas leituras.

Não devemos confundir a essência destilada de uma ideia que é infinita, com sua aplicação que é finita. A essência da ideia não está sujeita à mudança ao longo do tempos, embora sua aplicação seja variável em função do tempo, da percepção e da compreensão. (BAREMBOIM, 2008, p.50) 


\section{2- A criação musical, as improvisações e o processo editorial}

Algumas obras do século XVII e XVIII permitiam improvisações de seus intérpretes em alguns parâmetros da composição musical. NEUMANN (1986, p.247) informa que "W. A. Mozart (1756-1791) não tocava os adagios de seus concertos para piano simplesmente como estavam escritos, mas os embelezava com ternura e com muito gosto, e a cada vez diferentemente, seguindo a inspiração do seu gênio". No início do século XIX, a maioria dos compositores já demandava dos intérpretes uma atenção maior à notação musical. No entanto, o próprio Beethoven, conhecido pela exigência e precisão de sua notação

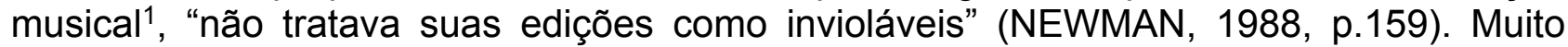
provavelmente, esta flexibilidade foi derivada da sua prática como improvisador. "Os testemunhos sobre a atividade de Beethoven como pianista destacam frequentemente a sua habilidade como grande improvisador" (CHIANTORE, 2010, p.211).

Em Chopin, o exercício da improvisação musical foi uma das prováveis causas das discrepâncias editoriais encontradas em seus textos musicais. Seu processo criativo estava sempre em progresso: desde os esboços iniciais às cópias e primeiras edições; todas incluíam alterações originais do compositor. Seus editores têm à disposição inúmeros manuscritos e partituras nos acervos pertencentes aos seus alunos e associados, entre eles: Jane Wilhermina Stirling (1804-1859), Camille Dubois O'Meara (1830-1907), a irmã do compositor Ludwika Jedrzejewicz (1807-1855), o violoncelista Auguste Franchomme (1808-1884), Zofia Zaleska-Rosengardt (1814-1868) e Napoléon Orda (1807-1883) (EIGELDINGER, 1986, p.198-266). CHIANTORE (2010, p.318) afirma que "seus próprios manuscritos diferem de tal modo uns dos outros que é impossível definir a superioridade de uma fonte sobre a outra." Nos últimos anos, houve acesso ilimitado às primeiras edições on-line, o que além de permitir a análise e a compreensão da obra chopiniana, possibilita uma comparação antes restrita a um grupo de editores e musicólogos. ${ }^{2} \mathrm{Em}$ todas as partes há inúmeras diferenças, como erros corrigidos, texto modificado (omissões, adições e mudanças de notas) e diferenças quanto aos dedilhados, indicações de tempo e caráter, fraseados, articulações e agógicas, instruções díspares para realização dos ornamentos, bem como da dinâmica e da pedalização. Além das discrepâncias entre os manuscritos e as primeiras edições, "muitas vezes, Chopin refazia as partituras para seus alunos mais talentosos, sugerindo variantes de dificuldade notável e também recompunha peças para aqueles alunos de musicalidade mais modesta" (CHIANTORE, 2010, p.317).

Vejamos um exemplo prático de algumas dessas diferenças editoriais, na reexposição do segundo tema do primeiro movimento na Sonata op.58 de Chopin: as edições aqui apresentadas são: a Édition de Travail de Alfred Cortot (1877-1962) ${ }^{3}$ idealizada para a Édition Salabert, a Édition Paderewski e a primeira edição francesa J. Meissonnier, de 1845. Segundo Karol Mikuli (1821-1897)4, aluno e assistente de Chopin, "o próprio compositor removeu o sustenido do Si (quarta nota) da cópia da edição original francesa (J. Meissonnier, Paris) e como resultado esse compasso não corresponde ao c.53 da exposição" (Ex.1). A Édition Salabert publicou a nota Si sustenido entre parênteses, com a seguinte observação de CORTOT (1930, p.19): "Chopin, ele mesmo, adicionou um sustenido antes do Si na edição original francesa" (Ex.2). Ao comparar as duas edições mencionadas com a primeira edição original francesa de 1845, confirmamos a discrepância (Ex.3). 


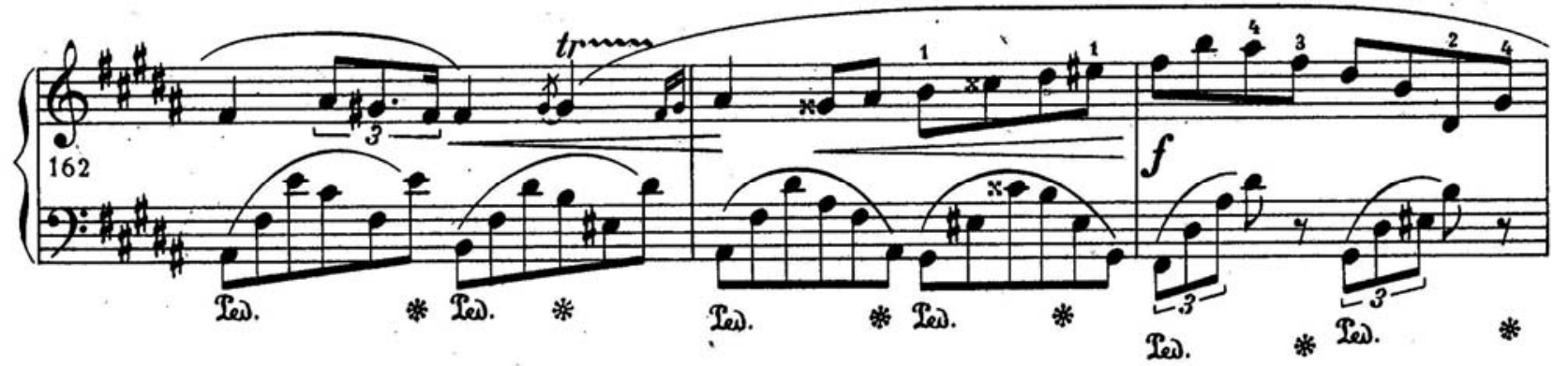

Ex.1. Chopin. Sonate op.58, $1^{\circ}$ mov. c.162-163, Ed. Paderewski, 1972.

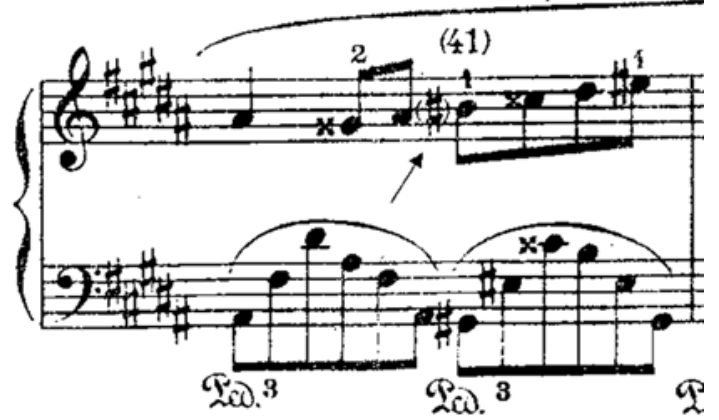

Ex.2. Chopin. Sonate op.58, $1^{\circ}$ mov. c.163, Ed. Salabert, 1930.

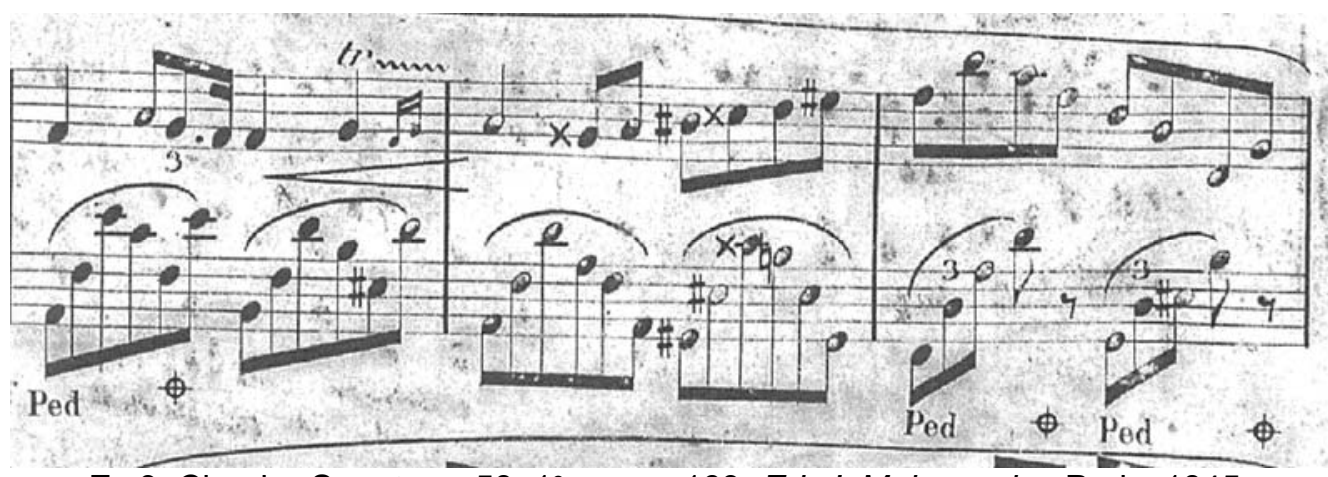

Ex.3. Chopin. Sonate op.58, $1^{\circ}$ mov. c.163, Ed. J. Meissonnier, Paris, 1845.

No mesmo exemplo, encontramos outras diferenças: o crescendo não existe na edição Salabert e na edição original francesa; na J. Meissonnier não há indicação de pedal, na edição Paderewski há sinal de soltura do pedal e na edição Salabert podemos interpretar o pedal como legato 5 . Observemos abaixo, outro excerto no desenvolvimento da mesma sonata (Ex.4 e Ex.5);

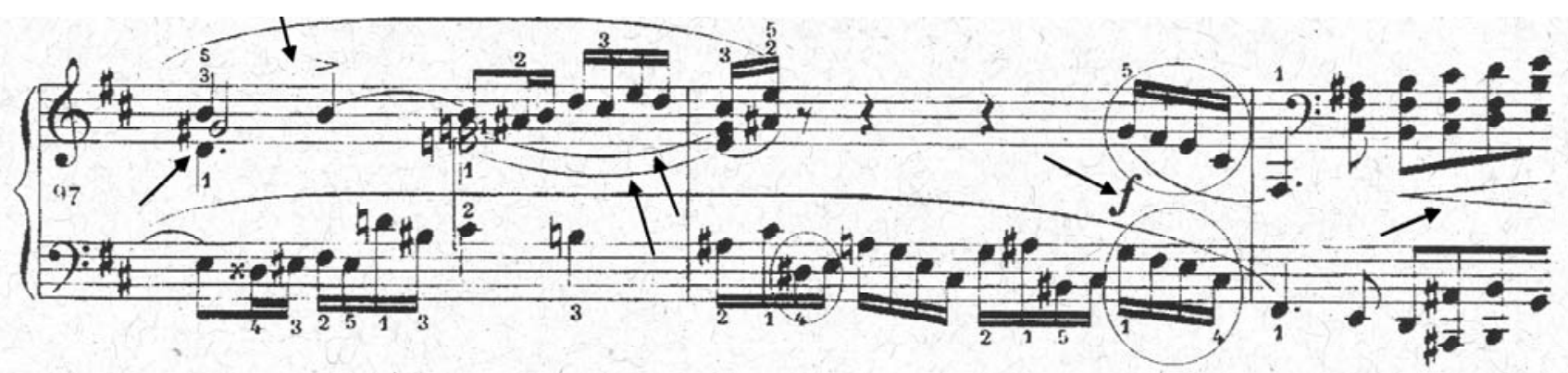

Ex.4. Chopin. Sonate op.58, c.97-99, Édition Salabert (Cortot), 1930. 


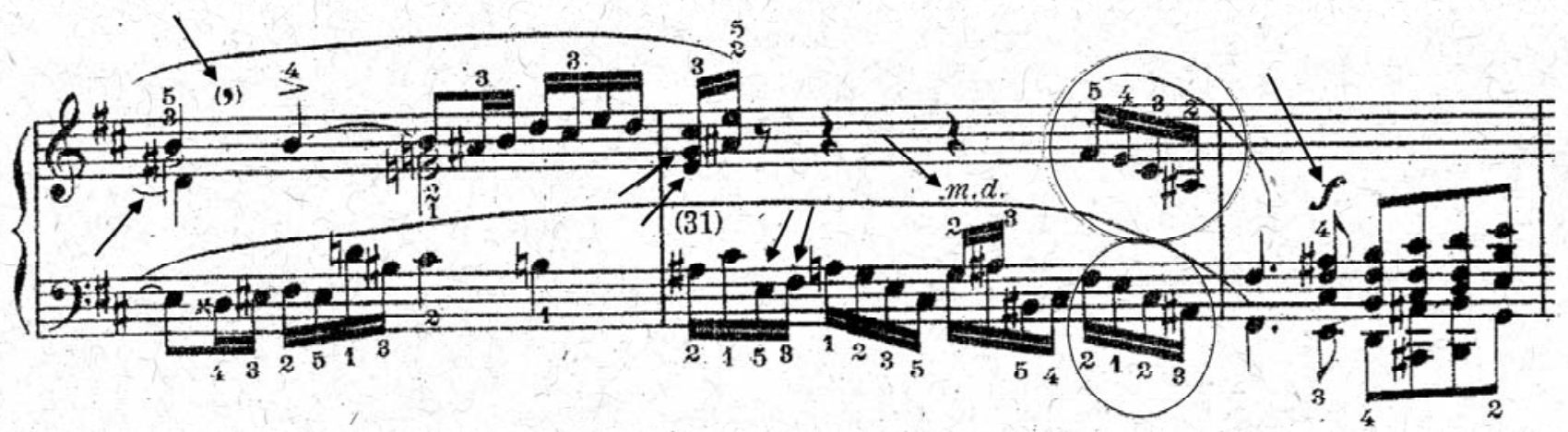

Ex.5. Chopin. Sonate op.58, $1^{\circ}$ mov. c.97-99, Édition Paderewski, 1972.

Podemos notar em apenas três compassos, as substanciais diferenças entre as duas edições. Há contradições em parâmetros diversos, como: notas discrepantes ou "corrigidas", sinais de dinâmica em diferentes posições, ligaduras omitidas ou acrescentadas, repetições de notas, dedilhados, articulações e mudanças timbrísticas, causadas pela alternância das mãos.

O costume de publicar suas obras separadamente na França, Alemanha e Inglaterra fazia com que [Chopin] produzisse outros tantos manuscritos de uma mesma composição, sem considerar as demais cópias que, em mais de uma ocasião, preparava especificamente como presente ou com outras finalidades. Se fosse uma simples operação mecânica, as cópias seriam idênticas, mas a realidade é outra. As diferenças são várias e afetam importantes detalhes rítmicos, melódicos e harmônicos, como observou apropriadamente Kalberg: Para Chopin era impossível limitar-se a copiar; para ele "copiar "sempre implicava em continuar compondo. A composição era para Chopin um processo aberto. (CHIANTORE, 2010, p.318)

Vejamos à seguir, o mesmo excerto anterior, nas três primeiras edições: a francesa J. Meissonnier, a alemã Breitkopf \& Härtel e a inglesa Wessel \& Co. Notar as diferenças substanciais de informações musicais entre as cinco publicações (Ex.4, Ex.5, Ex.6, Ex.7 e Ex.8):

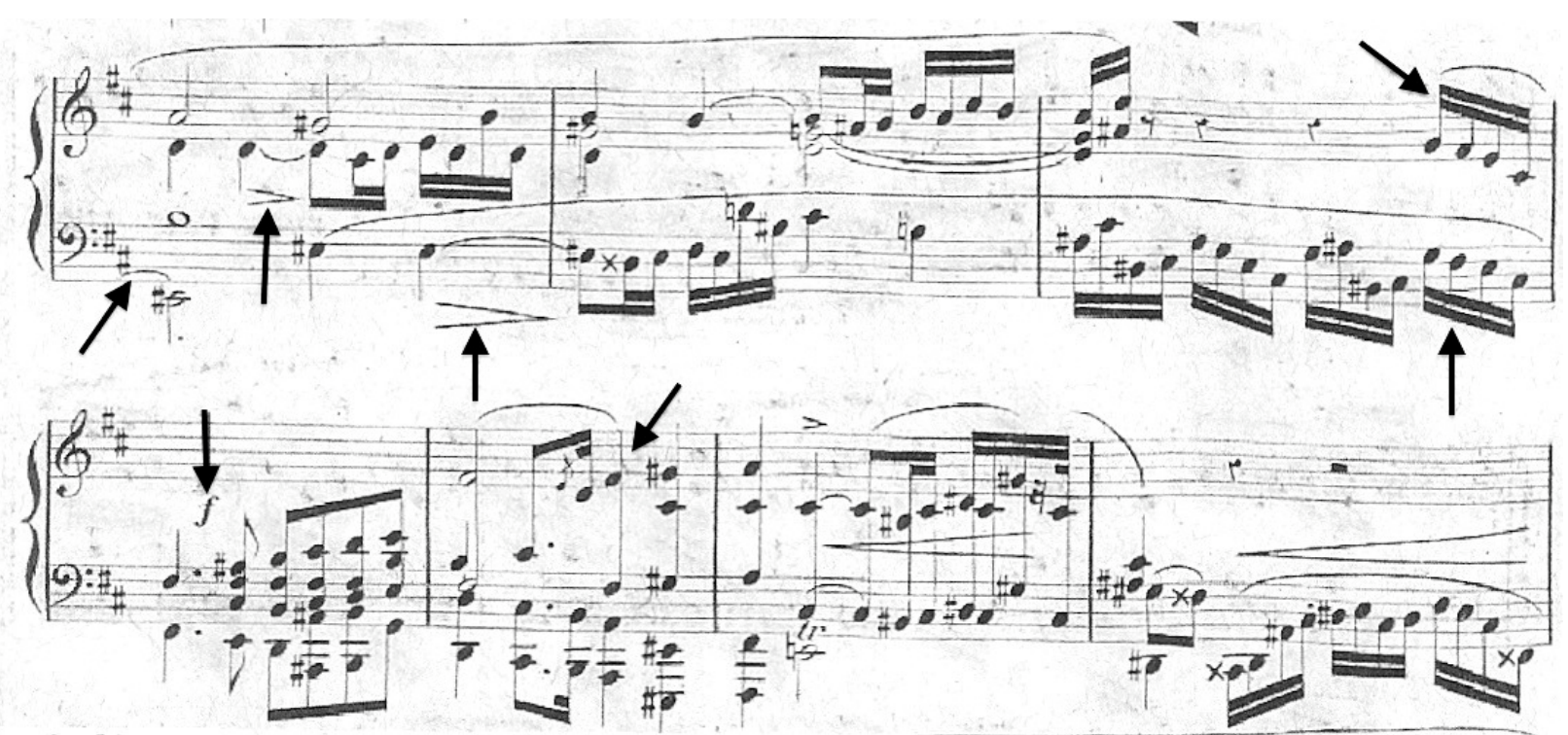

Ex.6. Chopin. Sonate op.58, $1^{\circ}$ mov. c.96-102, J. Meissonnier, $1^{a}$ edição francesa, 1845. 


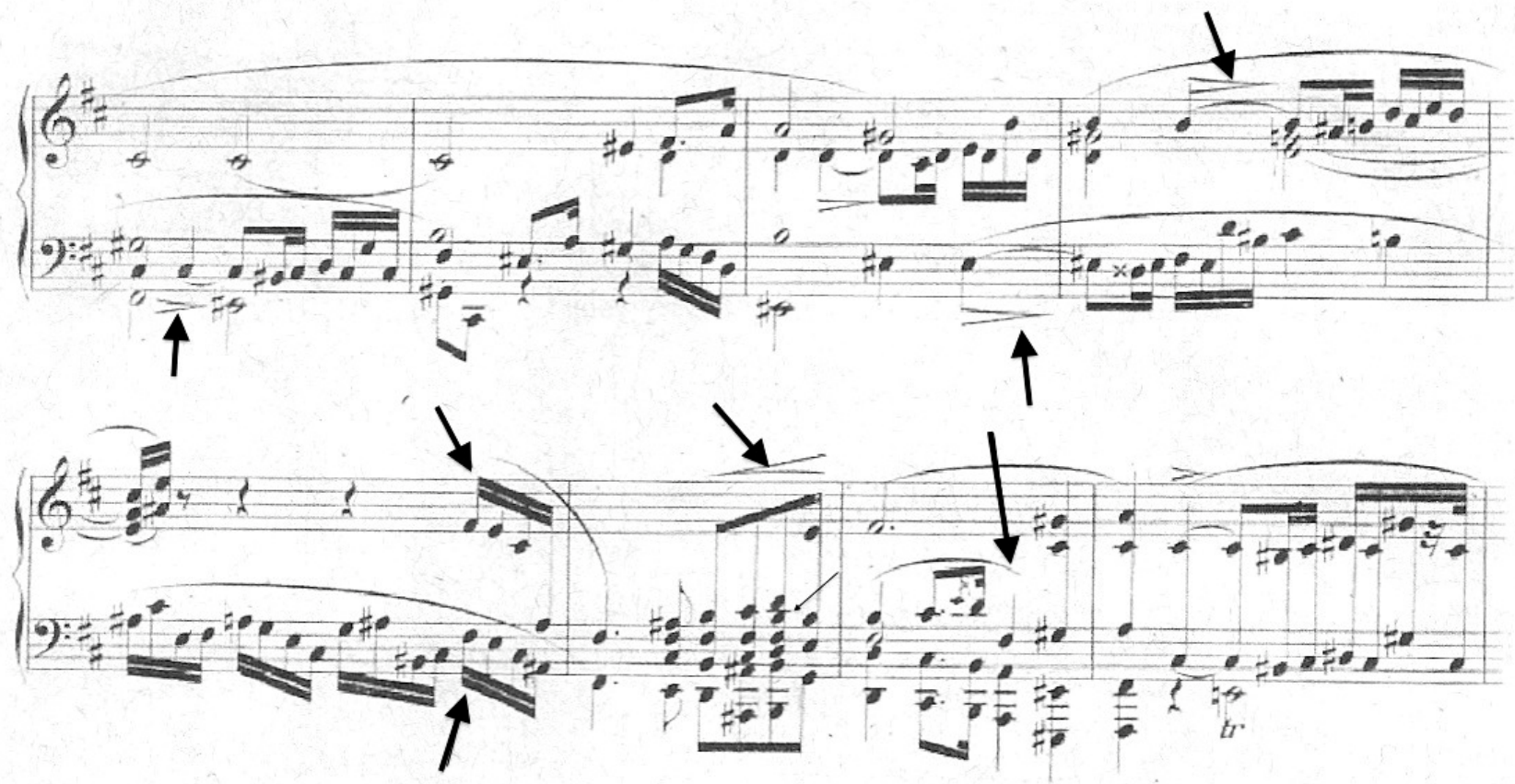

Ex.7. Chopin. Sonate op.58, $1^{\circ}$ mov. c.94-101, Breitkopf \& Härtel, Leipzig, $1^{\text {a }}$ edição alemã, 1845.

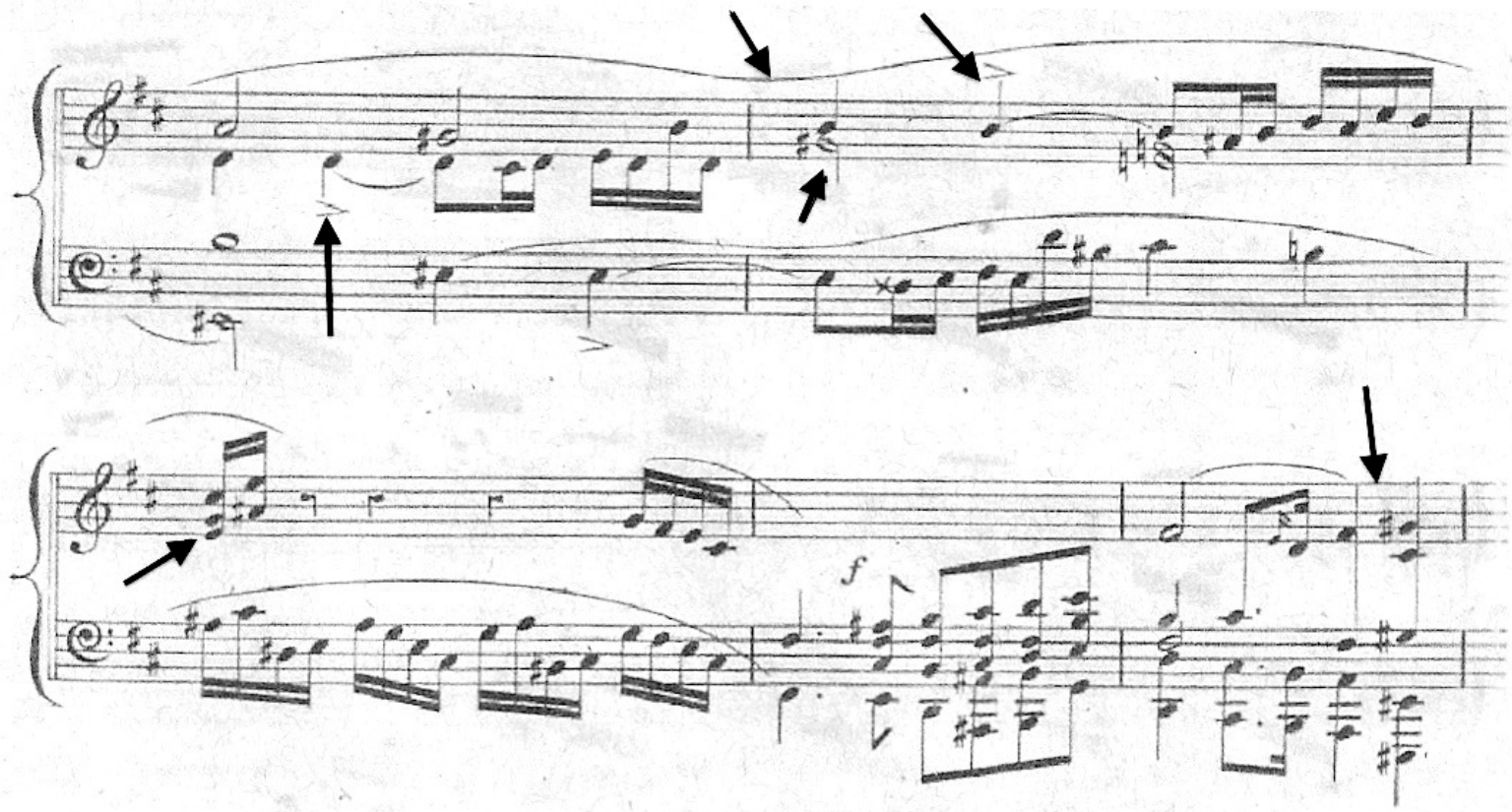

Ex.8. Chopin. Sonate op.58, $1^{\circ}$ mov. c.96-100, Wessel \& Co. $1^{\text {a }}$ edição inglesa, 1845.

Outro exemplo significativo ocorre no segundo movimento, Scherzo, desta mesma sonata. A alteração da nota Ré sustenido para Ré bequadro no c.117, adotado pela primeira edição alemã (Ex.9) e posteriormente pelas edições Paderewski e Salabert, trivializa uma harmonia bastante interessante e expressiva que aparece nas duas primeiras edições francesa e inglesa (Ex.10 e Ex.11). 


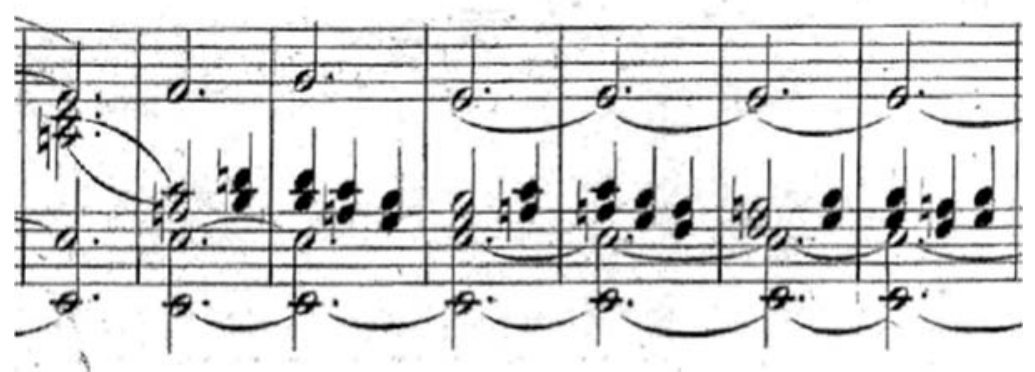

Ex.9. Chopin. Sonate op.58, $2^{\circ}$ mov. c.116-122, Breitkopf \& Härtel, Leipzig, $1^{\text {a }}$ edição alemã, 1845.

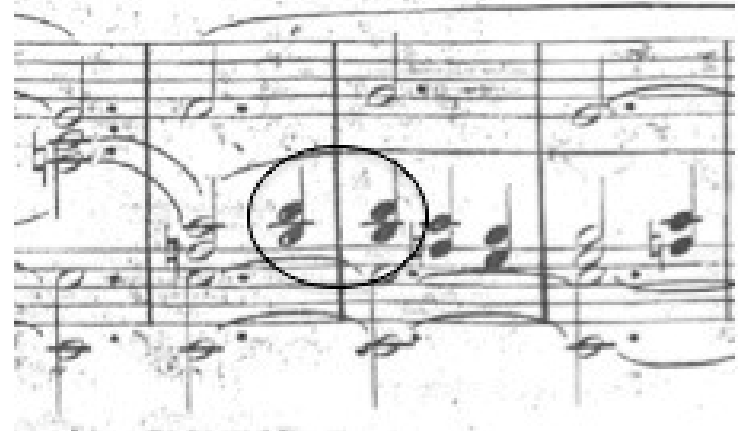

Ex.10. Chopin. Sonate op.58, $2^{\circ}$ mov. c.116-119, J. Meissonnier, $1^{\text {a }}$ edição francesa, 1845.

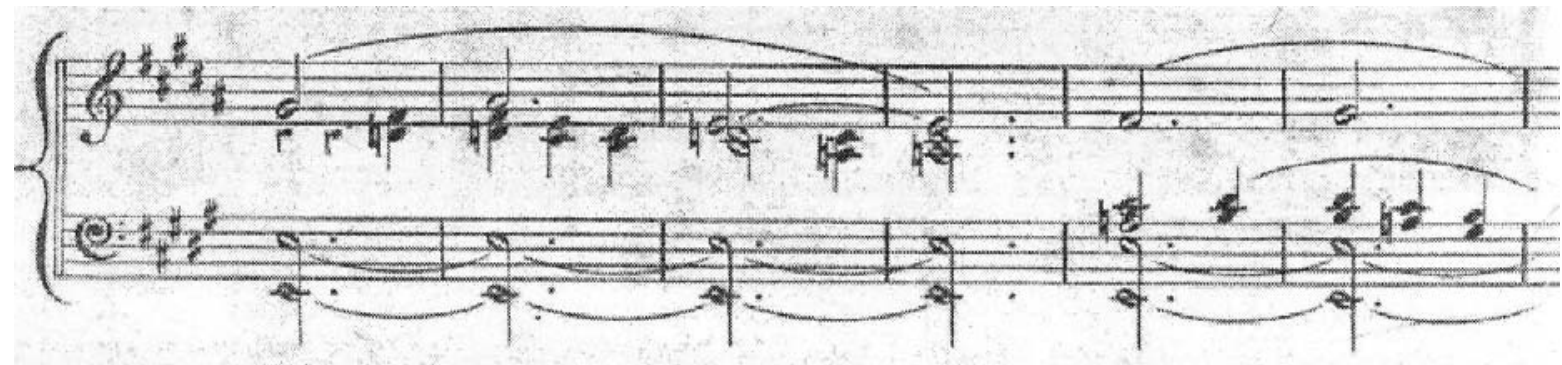

Ex.11. Chopin. Sonate op.58, $2^{\circ}$ mov. c.113-118, Wessel \& Co. $1^{\text {a }}$ edição inglesa, 1845.

Podemos inferir nos exemplos citados acima, que o acesso irrestrito às primeiras edições on-line, a maior facilidade de consulta aos tratados da estética romântica, o acesso aos documentos históricos sobre Chopin, juntamente com as memórias e registros dos pianistas e pedagogos, ampliaram consideravelmente as possibilidades de interpretação para o repertório chopiniano.

A seguir, veremos outras ambiguidades que ocorrem em diversos parâmetros da performance, tais como dedilhados, fraseados, rubati, pedais, ornamentações, agógicas, mudanças de caráter e tempo, que justificam ainda mais as novas propostas interpretativas.

\section{3 - Aspectos interpretativos e alguns paradoxos}

\section{1 - Origens do fraseado chopiniano}

De acordo com SAMSON (1994, p.81), Chopin "se familiarizou com a ópera italiana do inicio do século XIX durante sua formação em Varsóvia e durante suas visitas posteriores à Berlim e Viena". As numerosas récitas operísticas que aconteciam na Paris da década 
de 1830 consolidaram seu já bem estabelecido entusiasmo pelo assunto. Podemos inferir que a frase musical de Chopin, incluindo sua periodicidade e timbre, foi bastante influenciada pela prosódia e pela declamação poética. O compositor repetia, insistentemente: "É necessário cantar com os dedos!" (SAMSON, 1994, p.81). Chopin orientou sua assistente Vera de Kologrivoff Rubio (1816-1880) a tomar aulas de canto, afirmando que ela deveria se aprimorar no canto se quisesse tocar apropriadamente.

Paralelamente, os dois volumes do "Cravo Bem Temperado" de J. S. Bach (1685-1750) eram livros de cabeceira de Chopin, o que justifica sua habilidade ao escrever contrapontos expressivos com diversas linhas melódicas. Segundo CORTOT (1949, rep.2010, p.48), no repertório dos alunos mais avançados de Chopin, figuravam em lugar de honra os referidos Prelúdios e Fugas, que o mestre conhecia perfeitamente e era capaz de tocar sua grande maioria de memória, afirmando que "tais obras não podem jamais serem esquecidas". A influência bachiana surge e pode ser realçada em diversas obras de Chopin, como veremos, mais à frente, no Ex.13. "A música de Bach se exprime nas mais diversas linguagens estilísticas, mas sua abordagem deve ser renovada à cada interpretação" (BAREMBOIM 2008, p.51).

A importância da linha melódica e do contraponto em Chopin é ressaltada na seguinte afirmação de ROSEN (1995, p.85-6): "para Chopin, a linha melódica é mais básica do que a harmonia. Em passagens onde a textura e a harmonia parecem radicais e ambíguas, 0 contraponto é o agente controlador." A informação de Rosen pode ser melhor depreendida através das metodologias analíticas desenvolvidas pelo musicólogo Heinrich Schenker (1868-1935) ${ }^{6}$. Nas coletâneas Chopin's Studies I e II, editadas pela Universidade de Cambridge, em 1988 e 1994, são apresentados artigos de schenkerianos importantes como Carl Schachter, John Rink, Anthony Newcomb, Jim Samson, entre outros, cujos trabalhos demonstram os diversos níveis hierárquicos presentes na estrutura harmônico-melódica de Chopin. John RINK (1988, p.204) no artigo The Barcarolle: Auskomponierung and Apotheosis analisa o opus 60, desdobrando-o em estrutura principal (background), dois níveis intermediários (middlegrounds) e primeiro plano (foreground). "No primeiro plano há texturas muito contrapontísticas, onde percebe-se o jogo das linhas melódicas estabelecidas nos níveis estruturais mais remotos." Rink afirma que "Chopin revela sua grande arte composicional na elaboração do nível de primeiro plano (foreground), onde os ritmos, frases, dinâmicas, sonoridades e timbres sopram vida à fundação tonal da sua obra." (RINK, 1988, p.212).

\section{2 - A concepção de tempo e o cantabile chopiniano}

Segundo SAMSON (1994, p.82), a origem geral da cantilena chopiniana está mais ligada à tradição de Muzio Clementi (1752-1832), Jan Ladislav Dussek (1760-1812) e John Field (1782-1837) que à tradição do pianismo virtuosístico vienense de Wolfgang Amadeus Mozart e Johann Nepomuk Hummel (1778-1837). CHIANTORE (2001, p.326) menciona que, segundo as palavras dos próprios alunos de Chopin, a interpretação do mestre apresentava uma "declamação calma e não apaixonada". O uso de tais conceitos subjetivos nas práticas interpretativas são inevitáveis, e abrem portas bem-vindas para a liberdade e flexibilidade artísticas. A sensação de tempo, de arrebatamento e de passionalidade transformam-se constantemente, no tempo e no espaço ${ }^{7}$. 
CONE (1968, p.78-80) observa que "uma das tendências principais dos compositores do século XIX é a ênfase nas forças de contrastes, em detrimento das forças de unificação; fato que não se aplica somente ao tempo, mas também ao material temático, progressões harmônicas, ritmo e caráter". Segundo sua teoria, no classicismo, o compasso era a maior unidade métrica, enquanto que no romantismo, "e não no estilo precedente, nós poderíamos falar da tirania da frase de quatro compassos". O musicólogo demonstra, na seção intermediária da Fantasia-Improviso op.66, as aparentes irregularidades da frase romântica como um detalhe de superfície da estrutura fraseológica ordenada em "hipercompassos" regulares. As ideias analíticas de Cone podem ser aplicadas aos ensinamentos de Chopin, que recomendava que o pensamento interpretativo priorizasse sempre a grande frase. O compositor alertava que as intenções muito curtas atrapalhavam o fluxo musical, o desenvolvimento das ideias e fatigavam a atenção do ouvinte. "O bom intérprete deve cuidar para levantar e sustentar seu pulso, deixando-o cair somente na nota principal, empregando a maior flexibilidade possível durante a performance da frase. Obter essa flexibilidade é uma das tarefas mais difíceis que eu conheço!" (Gretsch-Grewingk, citado por EIGELDINGER, 1986, p.45). Segundo Chopin, "o pulso significa para o pianista o que a respiração representa para o cantor." (EIGELDINGER, 1986, p.45).

\section{3 - Rubato}

Em uma masterclass, a pianista Yara Bernette (1920-2002) procurou explicar a execução do rubato a um estudante, aludindo-se à imagem de uma balança de dois pratos, que para obter seu equilíbrio, necessita de um sistema de contrapesos. Assim sendo, um pequeno acellerando deveria ser compensado por um breve ritardando, e vice-versa. A imagem pode ser esclarecedora para uma explicação de efeito rápido e simples, mas na verdade, o rubato chopiniano está atrelado a elementos formais e de caráter, próprios de cada obra: o rubato aplicado à uma Mazurka será bastante diferente daquele usado para interpretar uma Balada ou para a concepção de uma obra extensa, em forma Sonata, por exemplo. Além dos aspectos formais e de caráter, a medida do rubato também relacionase com os elementos subjetivos da personalidade do intérprete, sua educação musical, humanística, seu momento artístico, assim como as influências exercidas pela filosofia e estética de sua época.

EIGELDINGER (1986, p.49) aponta para uma solução desvelada da história. De acordo com observações de alunos de Chopin, o rubato deveria ser realizado "mantendo-se estritamente o tempo da mão esquerda, quando da execução do acompanhamento, enquanto que a linha melódica flutuaria, com liberdade de expressão na mão direita."

Nos tão decantados tempo rubato, uma mão - que tenha o acompanhamento - sempre
toca em tempo estrito, enquanto que a outra, cantando a melodia, às vezes com
hesitação, com indecisão, com crescente animação, antecipando uma espécie de
impaciência veemente ou declarações apaixonadas, segue seu curso mantendo a
liberdade de expressão dos grilhões da regularidade estrita. (Mikuli, citado por
ROSENBLUM, 1991, p.382)

A cantora, pianista, compositora e amiga de Chopin, Pauline Viardot-Garcia (1821-1910) afirmou que esse procedimento é extremamente difícil de executar e requer do pianista uma completa independência motora. "É cem vezes mais fácil simplesmente manter-se o tempo, com as duas mãos juntas". Chopin afirmava que para o pianista, "a mão esquerda 
funcionaria como um regente de orquestra". Jan Kleczyńsky (1837-1895) afirma que muitas das passagens da Berceuse op.57, do Nocturne op.32 n² e do Impromptu em Láb op.29 deveriam ser interpretadas desta maneira. (EIGELDINGER, 1986, p.51).

Testemunhos dos alunos de Chopin informam que o compositor não permitia grandes digressões do tempo: "devemos nos lembrar que Chopin era contra os ritardandi exagerados ou fora do lugar." (HOLLAND, 1985, p.45). Inversamente, STRAUSS (1983, p.25) afirma que Chopin desejava que seus ornamentos fossem tocados com liberdade e que soassem como uma improvisação, à la cadenza e declarou que, em geral, "sua música não deve ser tocada com pedantismo, mas sim, com espontaneidade, elasticidade e flexibilidade."

A tentativa de mesurar-se o rubato chopiniano em uma frase musical poderá comprometer seu frescor e naturalidade, conferindo-lhe um caráter artificial. Tal atitude significaria coibir a flexibilidade emocional do pianista e ignorar sua conexão ao momento único da interpretação musical. Concluiremos as reflexões deste item com a observação de BAREMBOIM (2008, p.53) "toda interpretação musical está fundamentada sobre uma infinidade de possibilidades à nossa disposição. A partitura é substancia final, a obra terminada; mas sua interpretação tem uma expressão temporária, finita, que acontece no tempo, com começo e um fim".

\section{4 - Dedilhado}

Segundo ROSENBLUM (1991, p.213) dois tipos de dedilhados muito utilizados por Chopin e Schumann, foram herdados de Beethoven e Clementi: "o primeiro é a passagem de um dedo mais longo sobre outro menor (como 3 sobre 4 ou 4 sobre 5 também denominado überschlagen) ou um dedo menor sob um dedo mais longo (como 5 sob 4 ou 4 sob 3 também denominado unterschlagen)." O Ex.12 mostra esse tipo de dedilhado.

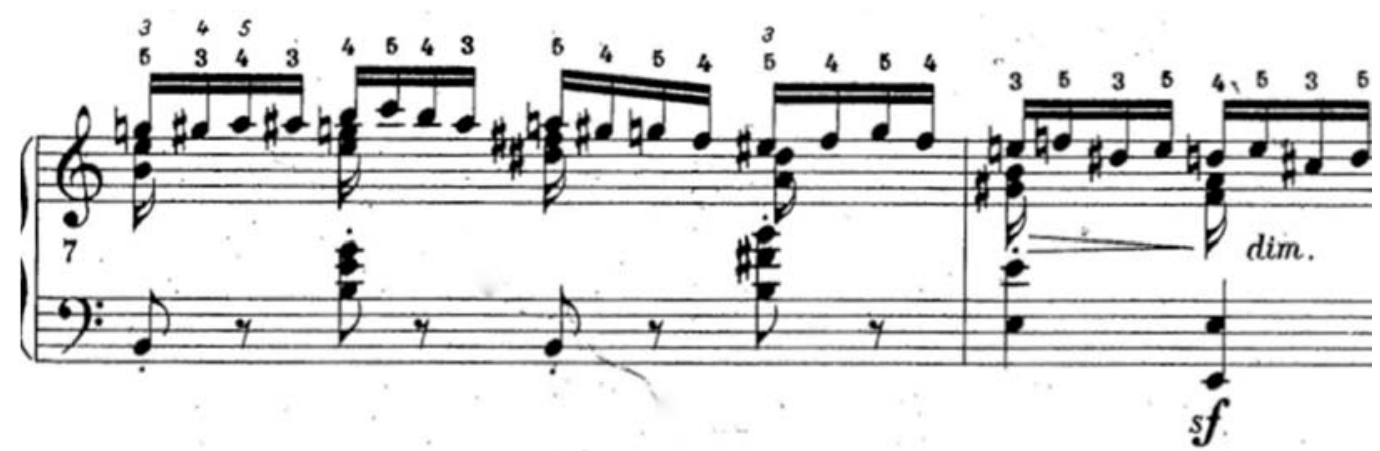

Ex.12. Chopin. Étude op.10 n², c.7-8, Édition Paderewski, 1949.

O segundo tipo, continua ROSENBLUM (1991, p.214), consiste em se "deslizar um dedo para uma tecla vizinha para obtenção do legato, de tecla branca para branca, de tecla branca para preta ou ainda de tecla preta para branca (esse ultimo, mais simples e de uso predominante durante o inicio do século XVIII)". Karol Mikuli citou esse dedilhado, muito utilizado por Chopin: "ele frequentemente usava o mesmo dedo para tocar graus conjuntos - e isso não somente quando escorregava da nota preta a branca - sem a mínima quebra da continuidade da linha melódica." (EIGELDINGER, 1986, p.46). Segundo ROSEN (1995, p.365), "esse tipo de dedilhado sinaliza uma ênfase musical específica, que aponta para uma maior expressividade e um ligeiro rubato." A observação 
refere-se ao tenuto, do verbo italiano tenere; cujo significado é segurar, manter. Assim sendo, o tenuto pode, tanto alterar a dinâmica quanto a duração de uma ou mais notas, enfatizando-as.

Sabemos, no entanto, que a escolha de um dedilhado irá depender da vertente técnica de cada pianista, do posicionamento de suas mãos, dos pulsos e cotovelos em relação ao teclado e também por fatores anatômicos individuais, como o formato das mãos, sua amplitude, flexibilidade, do tamanho e formato dos dedos. Alguns dedilhados tendem à padronização, como aqueles das passagens do polegar, estabelecidos nas escalas diatônicas, arpejos ou notas duplas, como terças, sextas e oitavas.

Segundo NEUHAUS (1971, p.146), observando-se grandes pianistas, "constata-se que seu toque, seu fraseado e seu jogo de pedais são tão diferentes como seu dedilhado, o que é um fato muito natural. A execução é sempre um ato de criação, portanto ela é individual e única." As disparidades nas sugestões editoriais dos dedilhados em Chopin podem ser observadas nos Ex.4 e Ex.5 deste artigo, mostrados acima. Lembremos que Claude Debussy (1862-1918), no prefácio dos seus Douze Études pour Piano (1915), afirma não existir nenhum bom dedilhado pré-estabelecido. "Um pianista que conhece música e seu instrumento, chegará facilmente, ele mesmo, à mesma conclusão de Debussy. A escolha do dedilhado ideal é resultado de uma boa escola, de experiência e de instinto." NEUHAUS (1971, p.156)

\section{5 - Pedal}

O uso do pedal sincopado, ou legato - que se contrapõe ao pedal rítmico, muito em voga no classicismo - só foi claramente descrito entre 1860 e 1870 . "Contudo, indicações sucessivas de pedal, sem sinais de solturas, são evidências do uso do pedal sincopado, e já ocorrem em algumas obras românticas da década de 1830, em algumas obras de Chopin e com maior frequência, em Liszt" (ROSENBLUM, 1991, p.106).

De acordo com as edições Henle e Schott dos Noturnos, há oito deles onde encontramos exemplos de pedal sem indicação de soltura em nenhuma das fontes. Muitas dessas indicações são sobre as ornamentações elaboradas (op.9 n², c.32-33) ou conectam passagens de transição ou notas do próximo tema (op.15 n¹ c.47-49), e algumas ocorrem onde qualquer respiração no uso do pedal causaria uma diminuição da intensidade musical (op.48 n² c.98-101) (ROSENBLUM, 1991, p.431).

O pianista Charles ROSEN (1995, p.298) afirma que "as indicações de pedal de Chopin são sempre muito carregadas". No entanto, o pianista Antoine François Marmontel (18161898), que conheceu o compositor pessoalmente, contrariou a informação:

Chopin usava os pedais maravilhosamente. Às vezes, o mestre os usava agrupados para obter uma sonoridade doce e velada e mais frequentemente ainda, ele os usava separadamente para interpretar passagens brilhantes, para sustentar harmonias, para aprofundar os baixos ou para timbrar e soar acordes. (EIGELDINGER, 1986, p.58)

Concordando com as informações de Marmontel, a edição Paderewski, assinala que "as marcas de pedal de Chopin são geralmente cuidadosas, precisas e em alguns lugares delicadas, o que muitas vezes produz um efeito pianístico totalmente novo". HINSON (1985, p.179) também aponta que "Chopin era muito cuidadoso nos seus manuscritos ao indicar suas intenções para o uso do pedal. Infelizmente, muitos dos seus editores 
negligenciaram suas diretrizes." Vejamos à seguir, um excerto que demonstra uma notável especificidade nas anotações de pedal para o Prélude op.28 n5 (Ex.13), criando uma espécie de hemíola de pedais.

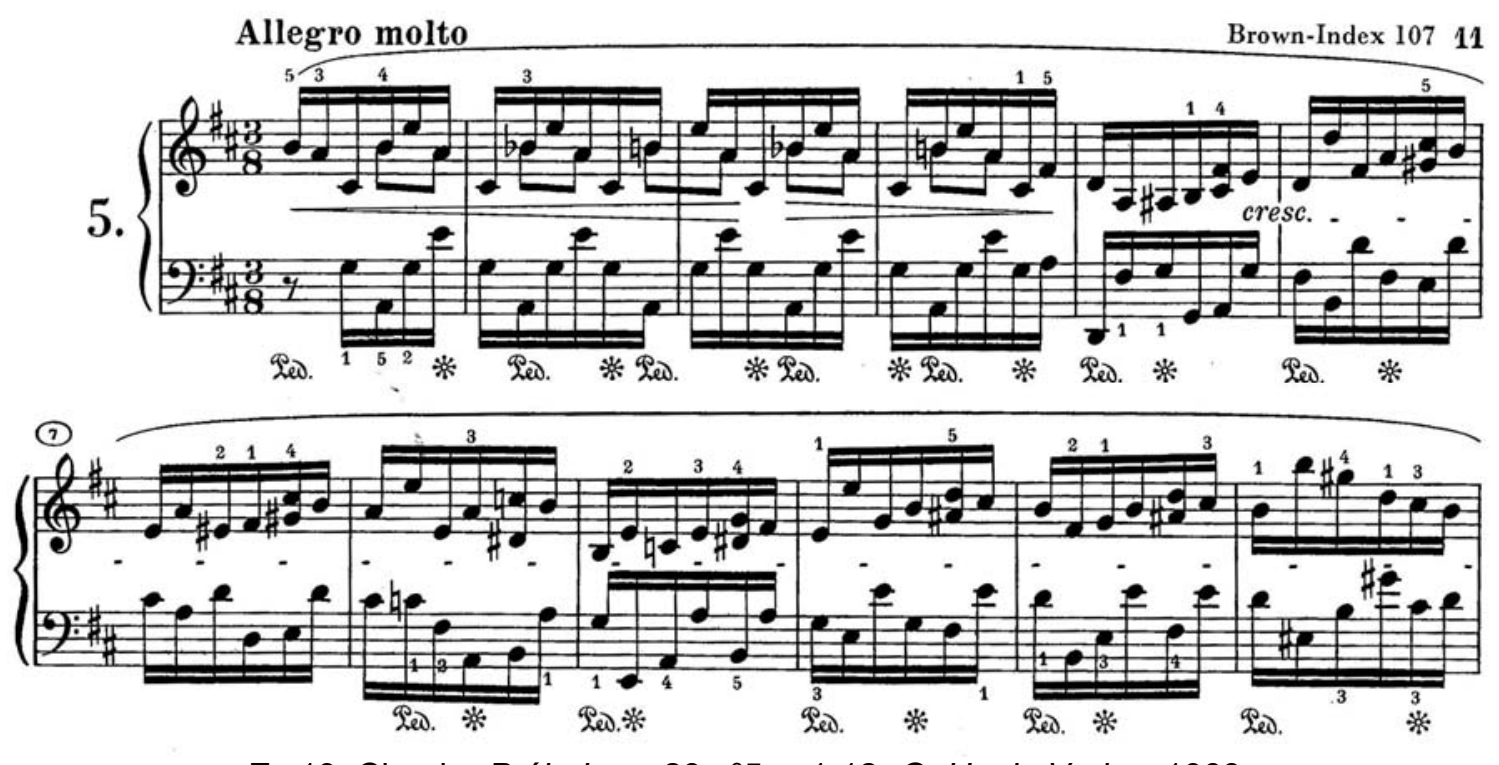

Ex.13. Chopin. Prélude op.28 n5, c.1-12. G. Henle Verlag, 1968.

As observações de Charles Rosen sobre as indicações carregadas dos pedais de Chopin podem ser relevadas, ponderando-se sobre as características essenciais dos pianos da época de Chopin:

As indicações originais de pedal de Chopin criam mais mistura de harmônicos nos instrumentos modernos que nos instrumentos da sua época, e isso deve ser levado em consideração pelo intérprete hoje em dia. Mas, o fato isoladamente não justifica ignorar suas diretrizes. O pianista que não considerar as indicações de Chopin está deixando de lado um elemento importante da intenção composicional. (HINSON, 1985, p.195)

O som dos pianos do início do século XIX tinham uma aura e uma clareza que se perdeu no som mais redondo e menos definido dos pianos modernos. Essas diferenças em som precisam ser consideradas quando estamos pedalizando obras escritas durante o século XVIII e XIX. (BANOWETZ, 1985, p.3)

Por outro lado, a opção por um pedal mais econômico, contrariando as indicações de Chopin, poderia ser justificada por duas razões: uma excessiva ressonância dos pianos Pleyel de escape simples e sua consequente adaptação aos pianos e ouvidos modernos, ou ainda um eventual desejo do intérprete de conferir certo caráter bachiano a este Preludio.

Devemos, no entanto, estar conscientes de uma particularidade importante da notação do pedal de Chopin, que aparece em alguns compassos finais de suas composições:

Chopin frequentemente omitia o sinal de soltura do pedal no final de suas obras. Podemos observar esse hábito nos Préludes op.28, números 1, 6, 7, 9, 11, 13, 16, 17 , 18, 19, 20, 21, 22, 23 e 24. Chopin parece deixar a soltura do pedal à critério do bom senso do intérprete. (HINSON, 1985, p.193)

Vejamos uma constatação deste fato no Prélude op.28 n6 (Ex.14 e Ex.15): 


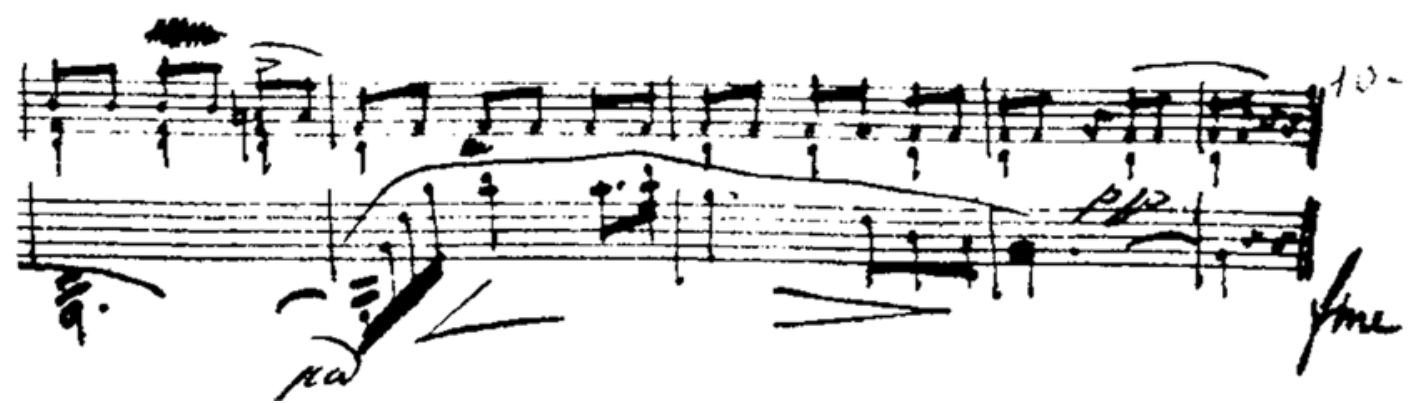

Ex.14. Chopin. Cópia do Manuscrito. Prélude op.28 n6, c.22-26. (1835-39). In: BANOWETZ, 1985, p.183.

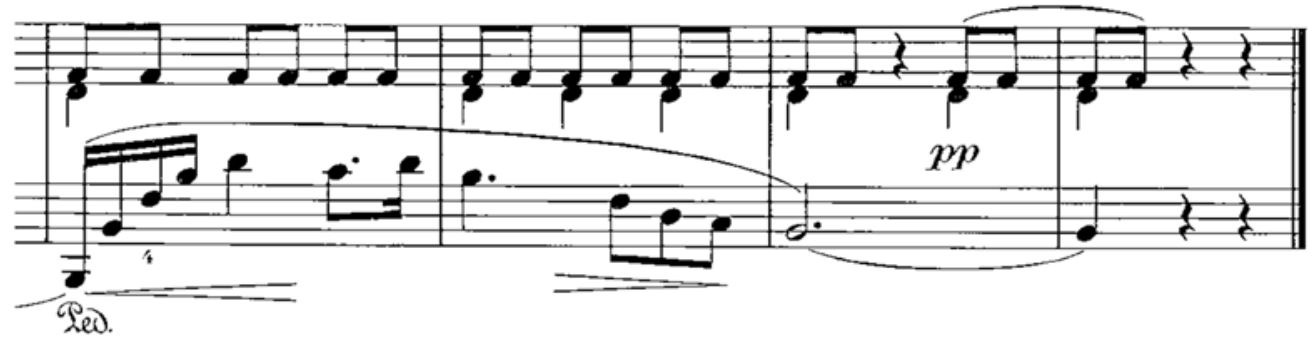

Ex.15. Chopin. Prélude op.28 n6, c.22-26. G. Henle Verlag, 1968.

A edição Henle reproduz a notação do manuscrito. No entanto, a edição Paderewski acrescenta deliberadamente um sinal de soltura de pedal, ao final da obra. Almejando a fidelidade ao texto musical, um intérprete poderá sentir-se compelido à sustentar o pedal sem interrupção, nos quatro compassos finais do referido Prelúdio op.28 n66. (Ex.16):

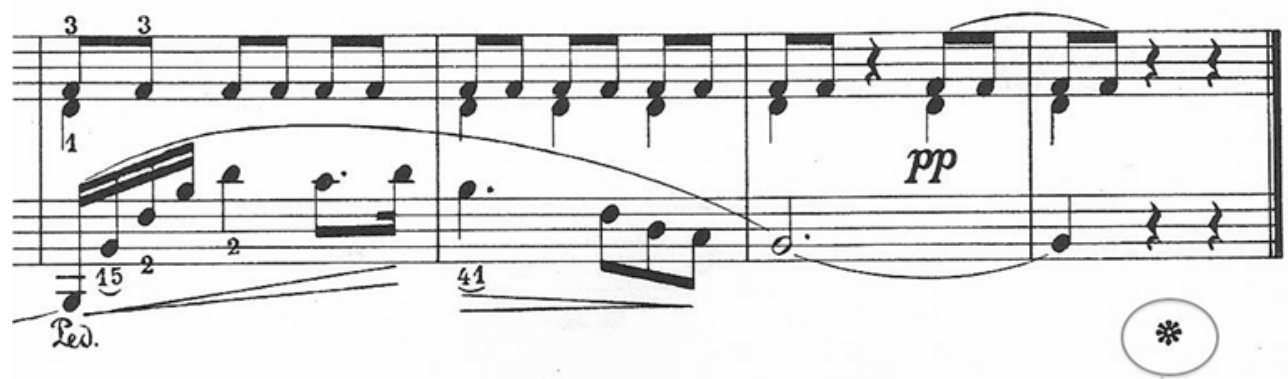

Ex.16. Chopin. Prélude op.28 n6, c.22-26. Edition Paderewski, 1990.

Vejamos outro excerto em duas edições diferentes, com discrepâncias na notação de pedal e no fraseado musical. $O$ fato poderá modificar a compreensão do ritmo fraseológico e alterar consideravelmente sua intenção interpretativa (Ex.17 e Ex.18):

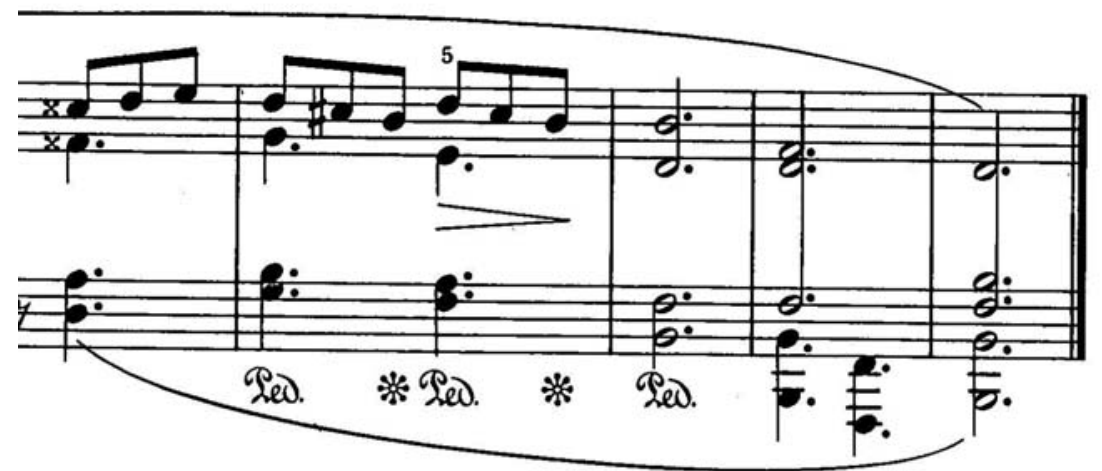

Ex.17. Chopin. Prélude op.28 n¹1, c.23-27. G. Henle Verlag, 1968. 


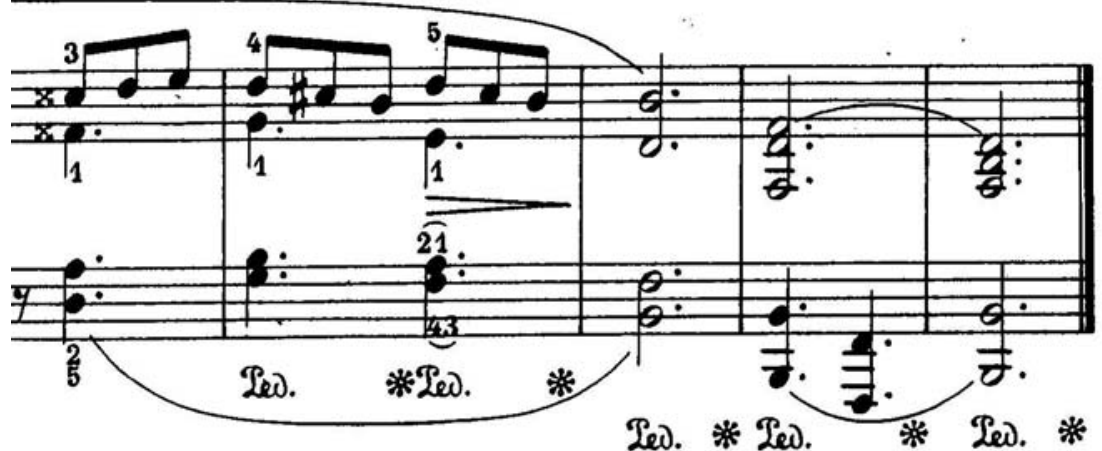

Ex.18. Chopin. Prélude op.28 n¹1, c.23-27. Edition Paderewski, 1990.

NEUHAUS (1971, p.158) observa: "eu toco oitenta por cento de toda minha música com meio pedal ou um quarto de pedal e vinte por cento, ou mesmo menos, com pedal inteiro." A sugestão pode ser utilizada na abordagem dos longos pedais do Quarto Scherzo op.54 (Ex.19):
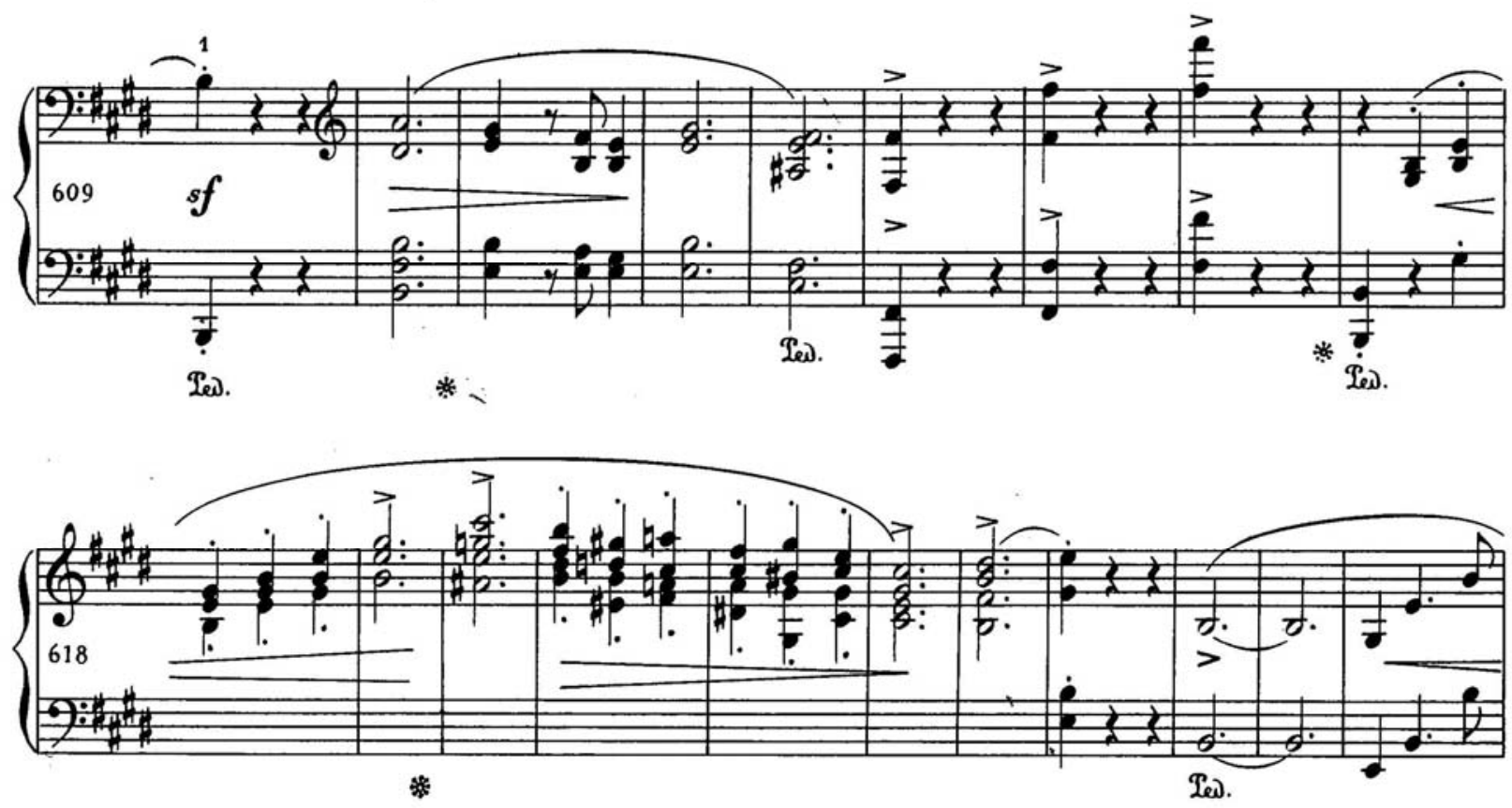

Ex.19. Chopin. Scherzo op.54, c.609-628. Edition Paderewski, 1988.

Nos compassos 609 e 614-16, nota-se outro procedimento usual em Chopin: o pedal sustentado nas pausas para criar-se um efeito cumulativo de harmônicos. No mesmo exemplo, nos compassos 617-18, também percebemos a aplicação do pedal simultaneamente com o toque staccato.

Deve-se tocar notas em staccato pedalizadas com o mesmo toque de quando as tocamos sem pedal. Notas em staccato com pedal têm um timbre levemente diferente do que as mesmas notas tocadas em legato, com pedal. (HINSON, 1985, p.193-195)

É importante lembrar que Chopin implantou sua marca na estética do pianismo românticoimpressionista francês, onde o pedal não só tem importância capital na criação de uma 
ambiência plena de ressonâncias e harmônicos, mas também está intimamente ligado à estruturação formal e estética de cada obra. CORTOT (1949, rep.2010, p.99-109) enaltece a "magia desta linguagem harmônica aérea, flexível e penetrante" que Chopin deixou na personalidade musical francesa, influenciando notadamente a música de Gabriel Fauré (1845-1924), Claude Debussy (1862-1918) e Maurice Ravel (1875-1937). Vejamos um exemplo que, segundo HINSON (1985, p.185) é um dos melhores exemplos do uso do pedal longo, de reverberação resoluta e grande intensidade expressiva (Ex.20):

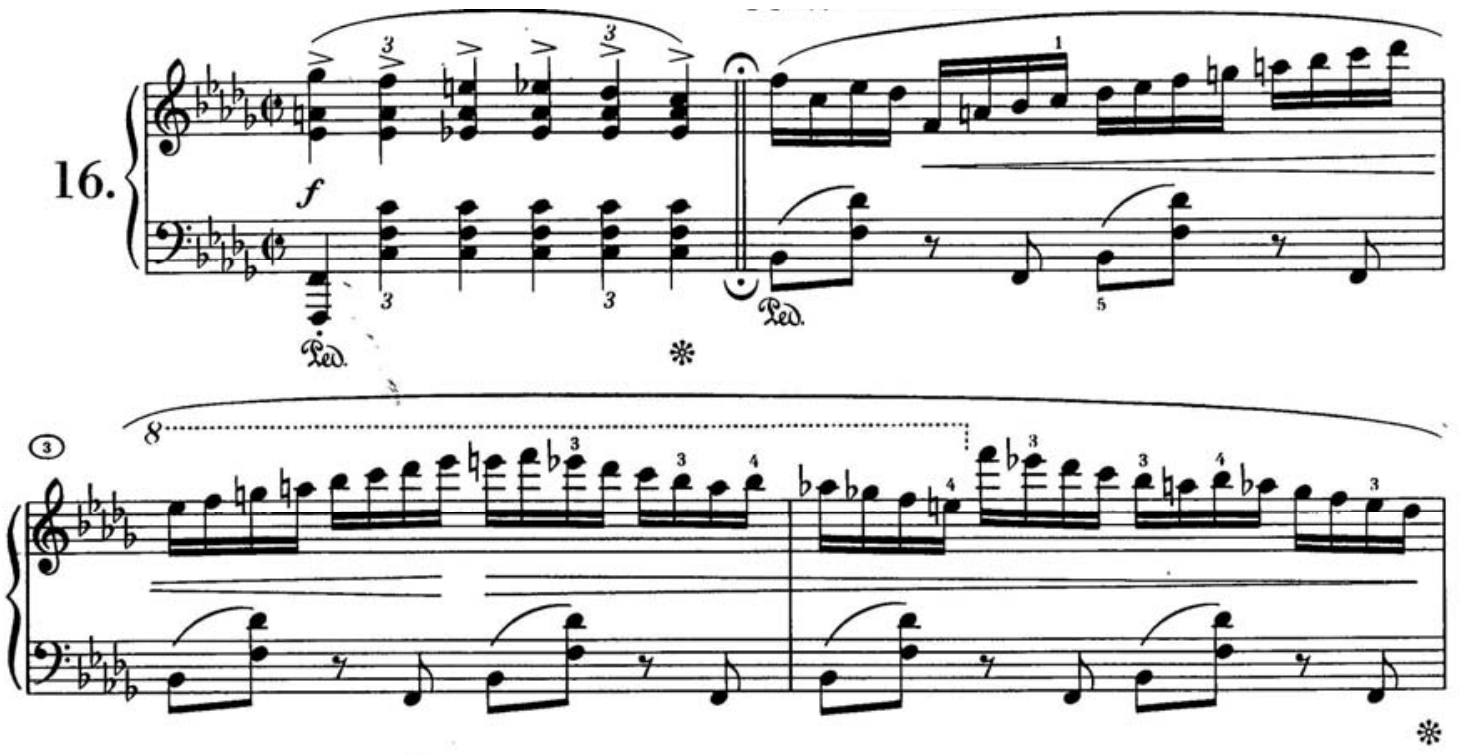

Ex.20. Chopin. Prélude op.28 n¹6, c.1-4. G. Henle Verlag, 1968.

Segundo HINSON (1985, p.194) "o pedal pode ser usado inteiramente em escalas ascendentes, quando são sustentadas por material harmônico, como é o caso das escalas do Prélude op.28 n²4". Chopin ocasionalmente usou pedal em longas escalas descendentes, como no caso da Barcarolle op.60 (Ex.21). Notar que a anotação do pedal impressa na primeira edição francesa (Ex.22) é fiel ao manuscrito pesquisado, mas a edição Paderewski desloca o sinal de pedalização original e não considera a articulação do fraseado, após o Fá\# final da escala descendente (Ex.23). 


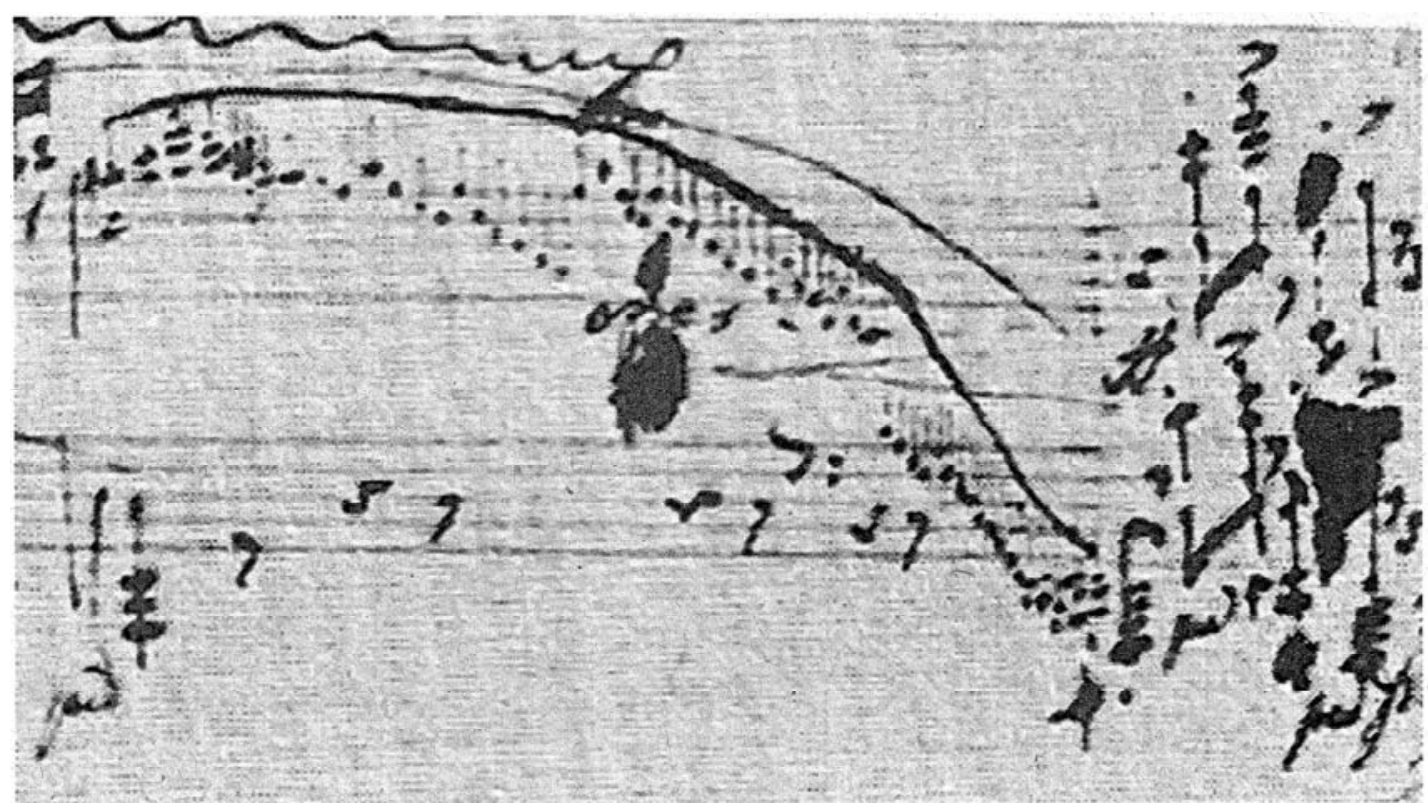

Ex.21. Chopin. Manuscrito Barcarolle op.60, c.115-116, 1845-46. (BANOWETZ, 1985, p.192)

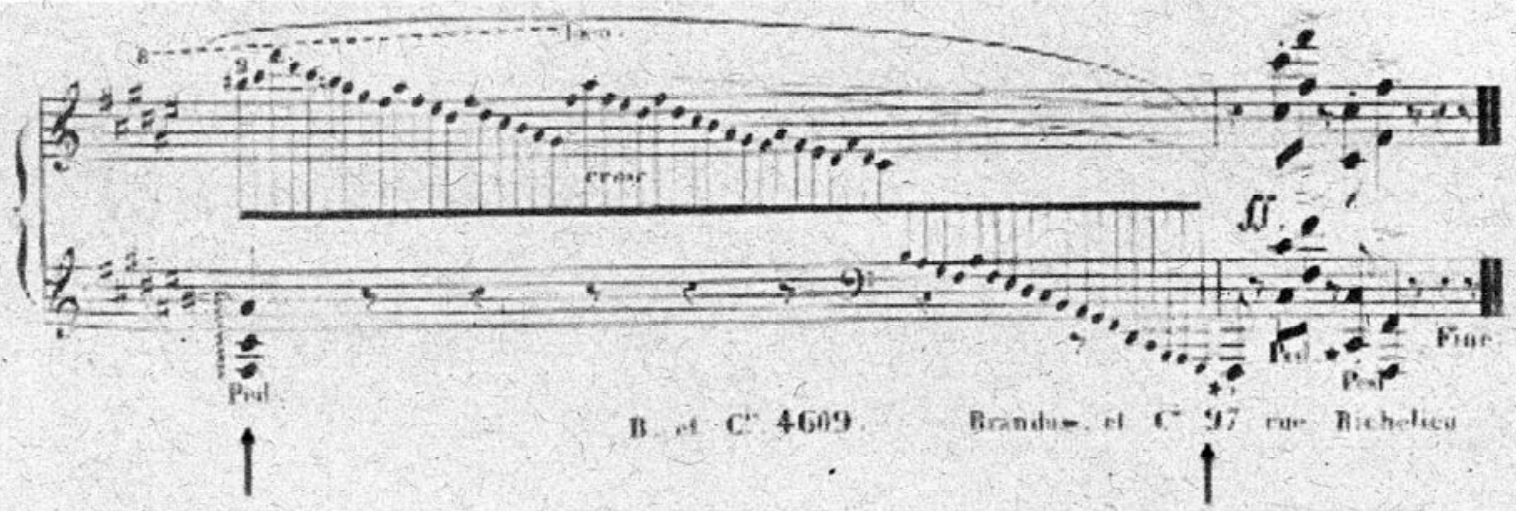

Ex.22. Chopin. Barcarolle op.60, c.115-116, Brandus \& Co. Paris (1ª edição francesa,1846).

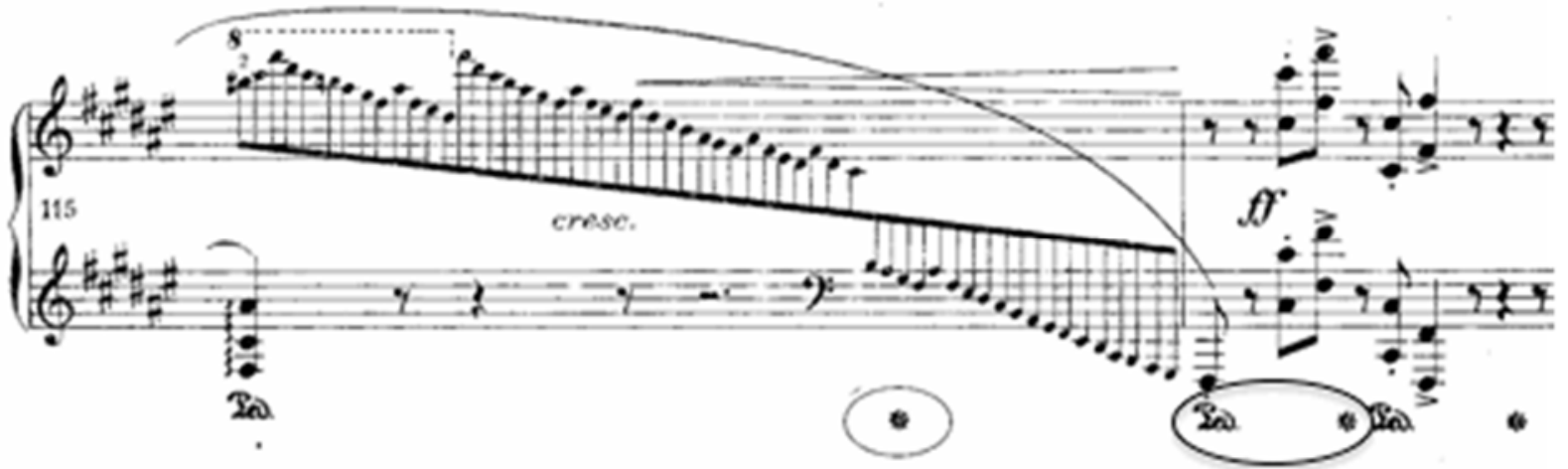

Ex.23. Chopin. Barcarolle op.60, c.115-116. Édition Paderewski, 1977.

Vejamos a seguir, algumas considerações a respeito do uso do pedal esquerdo - una corda - em Chopin. Como regra geral, NEUHAUS (1971, p.166) recomenda o uso do "pedal una corda somente em grandes períodos e frases musicais completas; em especial em momentos onde haja mudanças específicas de timbre." O pedagogo desaconselha o uso de una corda para obtenção da sonoridade $\boldsymbol{p}$ ou $\boldsymbol{p p}$. No entanto, esse conceito genérico não se aplica incondicionalmente à música de Chopin. "Embora Chopin nunca 
tenha indicado o uso do pedal una corda, seria incorreto concluir que ele nunca deve ser utilizado em suas obras" (HINSON, 1985, p.181). BANOWETZ (1985, p.115-121) sugere algumas exceções para flexibilizar essa regra: em mudanças súbitas da harmonia, como nos compassos 32 e 33 do Ex.24; em notas únicas de finais de frase; em transcrições, para obtenção de uma maior intensidade e expressividade do discurso musical; ou para realçar as diferenças timbrísticas entre o acompanhamento e a melodia, alternando-se os dois pedais (Ex.25).
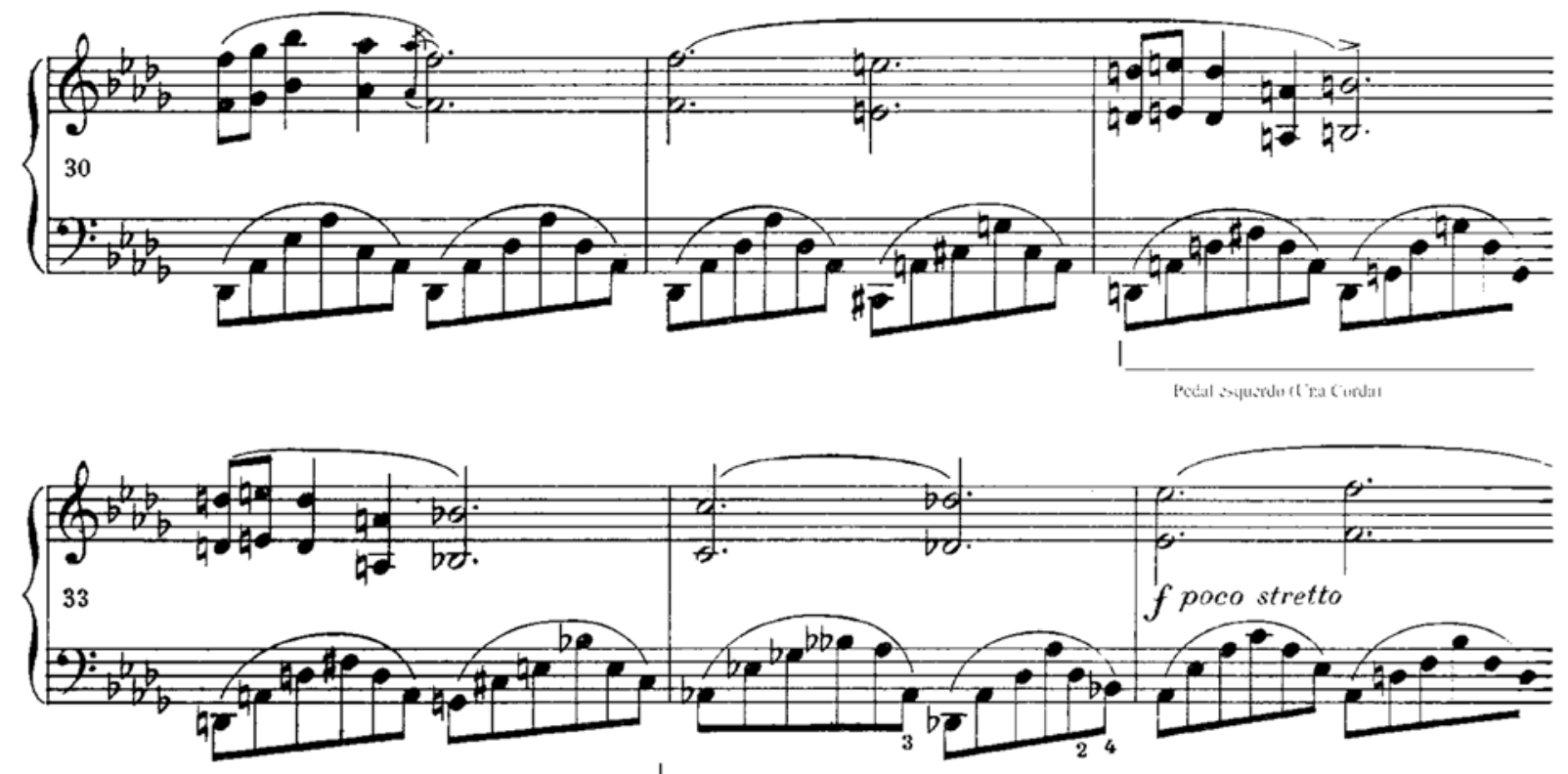

Ex.24. Chopin. Nocturne op.9 n¹, c.30-35. Édition Paderewski, 1979.

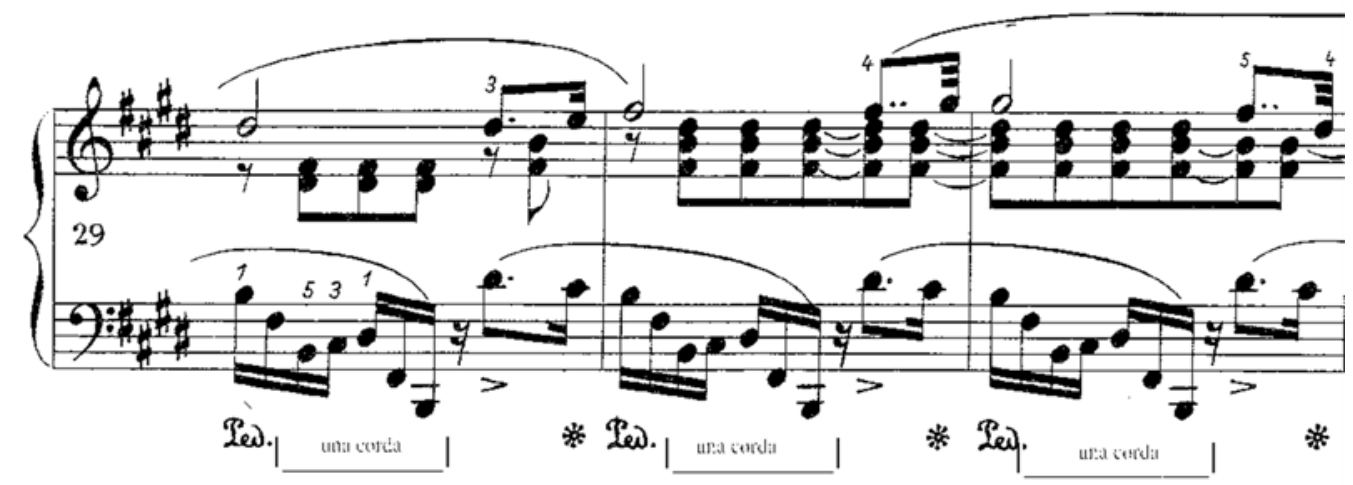

Ex.25. Chopin. Étude op.25 n7, c.29-31. Édition Paderewski, 1987.

Segundo Maurice Hinson, somente no final do século $X X$, começaram a surgir novas edições que consideraram, com precisão, as indicações originais de pedal de Chopin:

As edições Henle e Vienna Urtext traçaram bons passos nesta direção, assim como a Norton Critical Scores nos Préludes op.28. Novas edições mais e mais confiáveis estão sendo publicadas pela Edition Peters, Leipzig, editadas por Paul Badura-Skoda e Thomas Higgins e gradativamente se disponibilizam no mercado editorial. (HINSON, 1985, p.179) 


\section{6 - Ornamentação}

O pianista Paul Badura-Skoda sugere três princípios para se compreender a ornamentação:

Primeiro, um ornamento deve embelezar, o que significa que ele deve ser belo e agradável; segundo, deve haver uma relação harmoniosa entre o ornamento e o objeto embelezado, e assim ele deve ser leve, ou seja, sem peso. Um colar não deve ser maior que o corpo que ele adorna; terceiro, embora a aplicação de um ornamento deva ser regulado pela tradição e convenções composicionais, ela também requer uma certa liberdade. Se um tirano ordenar à todas as mulheres o uso da mesma joia, ela não será mais uma joia, mas um uniforme. (SKODA, 1993, p.253)

Segundo Pauline Viardot-Garcia, (EILGELDINGER, 1986, p.58) o trinado habitual de Chopin (Ex.26) deveria iniciar-se pela nota superior. A informação pode ser justificada pela reverência que o compositor dedicava à música de Johann Sebastian Bach, "cujos ornamentos começam geralmente pela nota superior" (TURECK, 1960, p.8). Por outro lado, devemos considerar a grande influência artística do pianista e compositor Jan Nepomuk Hummel em Chopin e em seus contemporâneos. Na terceira parte do seu método Escola Completa Teórico-Prática da Execução Pianística, desde as Primeiras Instruções até o Grau Mais Alto de Perfeição (1828), Hummel "traz uma descrição detalhada dos ornamentos, que vem encabeçada por uma moderníssima proposta: começar os trinados com a nota real" (CHIANTORE, 2001, p.242) ${ }^{8}$.

Podemos coligir que estamos abordando um período histórico de transição na prática da performance dos ornamentos. O assunto estava, na época, sendo discutido e abordado de diversas maneiras, entre os compositores e intérpretes. Instaura-se desse modo, mais uma ambiguidade nas diretrizes para realização desses parâmetros interpretativos na obra de Chopin, fato que se multiplica em várias interpretações autorizadas. Sobre a realização dos trinados, escreve Viardot-Garcia:

Quando os trinados são precedidos por uma nota pequena - de mesma altura da nota principal - isso não quer dizer que tal nota deva ser repetida, mas que o trinado iniciarse-á pela nota principal e não, como usualmente, pela nota superior." (EIGELDINGER, 1986, p.58-9).

Lento sostenuto

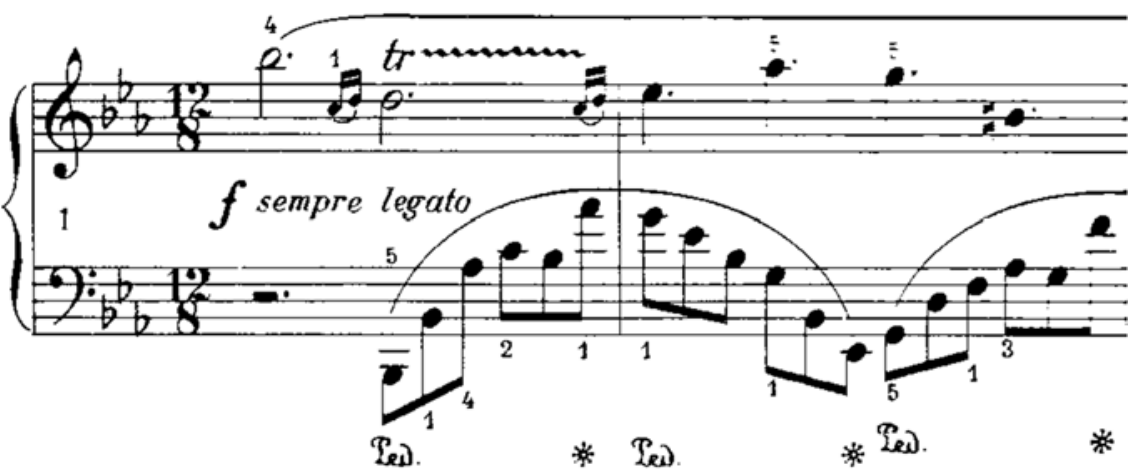

Ex.26. Chopin. Nocturne op.55 n², c.1-2. Edition Paderewski, 1979. 
A norma apresentada por Viardot não é unanimidade nas gravações pesquisadas, demonstrando que a personalidade artística do intérprete flexibiliza as normas históricas e contribui para a diversidade da interpretação ${ }^{9}$.

Ainda conforme instruções da edição Paderewski, todos os ornamentos, sejam eles apoggiaturas, mordentes, trinados, grupetos ou arpejos devem ser tocados "na cabeça" do tempo. Assim sendo, a duração do ornamento será subtraída da duração da nota principal, instrução que foi observada na maioria das gravações. Chopin era um verdadeiro mestre da ornamentação, tanto ao compor como ao tocar. Ele conhecia exatamente a função de cada ornamentação, seja ela rítmica, melódica ou harmônica:

Chopin explorava o uso dos ornamentos até o mais alto grau e o pianista que interpreta sua obra precisa ter conhecimento que Chopin escreveu seus ornamentos para fins específicos. $O$ instrumentista precisa estar ciente da execução dos ornamentos, suas exceções e estar apto a realizá-los musicalmente. (MAC CABE, 1984, p.212)

Os fundamentos estéticos da ornamentação, cadências, fraseados e dramatização do belcanto foram levados ao apogeu artístico por compositores como Gioachino Rossini (17921868) e Vincenzo Bellini (1801-1835), e se converteram em inspiração fundamental para a escola pianística chopiniana. As bases teóricas para o entendimento da estética vocal italiana, seus elementos e transformações entre 1650 e 1900, podem ser consultadas nos tratados Opinioni de' Cantori Antichi e Moderni, o Sieno Osservazione sopra il Canto Figurato (1723) de Pier Francesco Tosi (1653-1732), Pensieri e Riflessioni Pratiche sopra il Canto Figurato (1777) de Giovanni-Battista Mancini (1714-1800) e o Traité Complet sur l'Art du Chant (1840), de Manuel Patricio Rodríguez Garcia (1805-1906) (PACHECO 2006, p.27-46).

\section{4 - Conclusões}

As pesquisas históricas em práticas interpretativas do período romântico incluem vários conhecimentos provenientes de Chopin, de seus alunos e de seus contemporâneos. A pluralidade de informações contida nestes estudos flexibilizaram conceitos e provocaram mudanças profundas nos padrões interpretativos atuais. A performance musical daquele período estava fortemente vinculada às particularidades das manufaturas de seus instrumentos, cujas diferenças mecânicas e timbrísticas ainda eram bastante consideráveis durante o romantismo. Tal fato valida uma importante tendência da interpretação e análise atuais, que entende que algumas destas normas estéticas e musicais românticas são adaptáveis à individualidade dos seus intérpretes, levando-se em consideração seu momento, sua época e seu instrumento.

Constatou-se também que uma única referência editorial não corresponde às pretensões musicais de Chopin. Os conflitos de informações contidos nas primeiras edições da obra do compositor representam um sério dilema para seus editores; mas por outro lado, se tornam um instigante desafio interpretativo para os intérpretes e musicólogos. As diferenças destas primeiras edições vão desde as muito evidentes, como discrepâncias entre notas e ritmos que transformam o sentido contrapontístico e harmônico; até as variações mais sutis, mas não menos importantes, como o posicionamento das ligaduras de fraseado, dos dedilhados, ornamentações, articulações, pedais, dinâmicas e rubati. 
Portanto, infere-se que as interpretações da obra de Chopin podem variar sensivelmente, tanto por suas adaptações individuais, instrumentais e estéticas, como por suas notáveis diferenças editoriais. Forma-se, portanto, uma rede de possibilidades que suscitam leituras diversas, capazes de evidenciar as influências estilísticas herdadas do passado ou de apresentar as inovações sonoras de um compositor à frente de seu tempo.

Conclui-se que a objetividade e a subjetividade coexistem na escrita musical chopiniana e nas suas diversas interpretações, originando camadas conceituais interdependentes. $O$ atual dinamismo das pesquisas históricas flexibiliza as informações e os conhecimentos adquiridos, cria alguns paradoxos, mas também transforma muitos paradigmas. A constante reinvenção interpretativa na música de Chopin originou-se nas próprias ideias e improvisações do compositor, transformou-se pelas opiniões e edições de seus alunos e vem se confirmando até os dias de hoje, pela diversidade da produção artística de várias gerações de pianistas.

\section{Notas}

1 Conforme declaração do compositor à seu aluno Carl Czerny (1791-1857) em 1816 (NEWMAN, 1988, p.159).

${ }^{2}$ As primeiras edições das obras de Chopin podem ser acessados no site Chopin First Editions On Line http://www.cfeo.org.uk/jsp/browsecollection.jsp, acesso em 2 de junho de 2014.

${ }^{3}$ Alfred Cortot estudou no Conservatório de Paris com Émile Descombes (1929-1912), que segundo alguns estudiosos, foi um dos últimos alunos de Chopin. O pianista foi um grande especialista na obra do compositor polonês e adquiriu vários dos seus manuscritos em Londres em 1936, além de ter gravado muitas das suas obras para piano (SCHONBERG, p.406-7).

${ }^{4}$ A informação faz parte das notas de programa da Édition Paderewski (1972, p.132).

${ }^{5}$ Consultando-se registros fonográficos, observamos que as artistas Elizabeth Leonskaya (Teldec, 1989) e Martha Argerich (Deutsche Grammophon, 1974, 2010) optaram pelo Si bequadro em suas interpretações.

6 Heirich Schenker estudou com Karol Mikuli, assistente de Chopin, em Lemberg, hoje Lviv, Ucrânia (SAMSON, 1985, p.228, n.53).

7 Interessantes concepções de tempo e liberdade musical aparecem expressas na correspondência entre Edward Steuermann (1892-1964) e Michael Gielen (1927-). Steuermann foi pianista, compositor e professor e se destacou como intérprete notável do repertório produzido pela Segunda Escola de Viena, mas também foi importante intérprete de Chopin. Seu sobrinho, Michael Gielen, tornou-se maestro, é especialista na obra de Gustav Mahler (1860-1911) e foi grande divulgador da música de seu tempo. Em 06 de junho de 1942, Gielen, que na época contava com quinze anos e habitava à Buenos Aires, escreveu ao seu tio, indagando sobre detalhes interpretativos das seis pequenas peças pós-românticas que formam os Klavierstücke op.19 de Arnold Schoenberg (1874-1951). Em 24 de julho de 1942, Steuermann respondeu: "Em relação à interpretação, você me pergunta se deve tocar estritamente à tempo, ou com liberdade. É difícil responder, a mais de seis mil milhas de distância e sem realmente saber o que você entende por a tempo e por liberdade". Inquirido sobre qual a medida metronômica da primeira peça, Steuermann respondeu: "Eu começaria a primeira peça com a colcheia mais ou menos igual a 100. $(\delta=100$, pelo menos hoje (sic), em Santa Mônica, Califórnia. Em Buenos Aires pode ser diferente e isto não é uma piada)." (Carta cedida pelo Prof. Dr. Amilcar Zani, responsável pelo projeto Vida e Arte na coleção Clara e Edward Steuermann, ECA-USP).

8 Os trinados executados por Arthur Rubinstein (1887-1982), quando não precedidos de apoggiatura, começam frequentemente pela nota real. Aqueles executados por Guiomar Novaes (1894-1979) e por Claudio Arrau (1903-1991) iniciam-se pela nota superior em todas as gravações pesquisadas.

9 Arthur Rubinstein (RCA Victor, 1949/1950) realiza o trinado do Ex.23, repetindo a nota real simultaneamente com o baixo. Claudio Arrau, (Philips, 1978) começa com a nota superior e toca o baixo com a primeira nota da apoggiatura, ou seja, com a nota Dó. 


\section{Referências}

\section{Textos}

BADURA-SKODA, Paul. Interpreting Bach at the Keyboard. Oxford: Claredon Press, 1993.

BANOWETZ, Joseph. The Pianist's Guide to Pedaling. Bloomington: Indiana University Press, 1985.

BAREMBOIM, Daniel. La Musique Éveille le Temps. Paris: Librairie Arthème Fayard, 2008.

BILSON, Malcolm. Do We Really Know How to Read Urtext Editions? In: Piano \& Keyboard. July/August 1995, p.24-30.

CHIANTORE, Luca. Beethoven al Piano. Barcelona: Nortesur, 2010. . Historia de la Técnica Pianística. Madrid: Alianza Editorial, 2001.

CONE, Edward. Musical Form and Musical Performance. New York: Norton \& Company, 1968.

CORTOT, Alfred. Aspects de Chopin. Paris: Albin Michel, 1949, rep.2010. Curso de Interpretación. Buenos Aires: Ricordi Americana, 1934.

EIGELDINGER, Jean-Jacques. Chopin Pianist and Teacher as Seen by his Pupils. Great Britain: Cambridge University Press, 1986.

HINSON, Maurice. Pedaling the Piano Works of Chopin. In: BANOWETZ, Joseph. The Pianist's Guide to Pedaling. Bloomington: Indiana University Press, 1985.

HOLLAND, Jeanne. Chopin the Teacher. In: Journal of the American Liszt Society. №17 (1985), p.39-48.

HOROWITZ, Joseph. Arrau on Music and Performance. New York: Dover Editions, 1982.

HUNEKER, James. Chopin: The Man and His Music. New York: Dover Editions, 1966.

Mac CABE, Patricia Chu-Li. The Piano Pedagogy of Frederic Chopin. M.A. Thesis, San José State

University, 1984.

NEUHAUS, Heinrich. L'Art du Piano. Paris: Éditions Van de Velde, 1971.

NEUMANN, Frederick. Ornamentation and Improvisation in Mozart. New Jersey: Princeton University Press, 1989.

NEWMAN, William. Beethoven on Beethoven: Playing his Piano Music His Way. New York: W.W.Norton \& Company, 1988.

PACHECO, Alberto. O Canto Antigo Italiano: uma Análise Comparativa dos Tratados de Canto de Pier Tosi, Giambattista Mancini e Manuel P. R. Garcia. São Paulo: Annablume/FAPESP, 2006.

RINK, John. The Barcarolle: Auskomponierung and Apotheosis. In: SAMSON Jim, ed. Chopin Studies. Cambridge University Press, 1988. p.195-219.

ROSEN, Charles. The Romantic Generation. Cambridge, Massachusetts: Harvard University Press, 1995. ROSENBLUM, Sandra. Performance Practices in Classic Piano Music. Bloomington: Indiana University Press, 1991.

SCHACTER, Carl. Chopin's Fantasy op.49: the two key scheme. In: SAMSON Jim, ed. Chopin Studies. Cambridge University Press, 1988. p.221-253.

SAMSON, Jim. The Music of Chopin. Oxford: Claredon Press, 1994.

SCHONBERG, Harold. The Great Pianists: From Mozart to the Present. New York: Simon \& Schuster, 1987. STRAUSS, J. F. The Puzzle of the Chopin Rubato. In: Clavier. No.22 (May 1983), p.22-25.

TURECK, Rosalyn. An Introduction to the Performance of Bach. 3 vol. London: Oxford University Press, 1960.

TRANCHEFORT, François-René. La Musique de Piano et de Clavecin. Paris: Librairie Arthème Fayard, 1987.

\section{Partituras}

CHOPIN, Fréderic. Barcarolle op.60. Édition Paderewski. Cracóvia: Instytut Fryderyka Chopina, 1977. Études. Édition Paderewski. Cracóvia: Instytut Frideryka Chopina, 1987. Nocturnes. Édition Paderewski. Cracóvia: Instytut Fryderyka Chopina, 1979. Préludes. Édition Paderewski. Cracóvia: Instytut Frideryka Chopina, 1990. Préludes. Édition Ewald Zimmermann. München: G. Henle Verlag, 1968. Scherzos. Édition Paderewski. Cracóvia: Instytut Fryderyka Chopina, 1988. Sonatas. Édition Paderewski. Cracóvia: Instytut Fryderyka Chopina, 1972. Sonata op.58. Édition de Travail par Alfred Cortot. Paris: Éditions Salabert, 1930. 
Partituras de primeiras edições (Download realizado no site Chopin First Editions Online, em 2 de junho de 2014. http://www.cfeo.org.uk/apps/)

CHOPIN, Frédéric. Barcarolle op.60. Paris: Édition J. Meissonnier,1846. Sonate op.58. Paris: Édition J. Meissonnier,1845. Sonate op.58. Leipzig: Édition Breitkopf \& Härtel, 1845. Sonate op.58. London: Édition Wessel \& Co. 1845.

\section{CDs}

CHOPIN, Frédéric. Argerich plays Chopin. Martha Argerich. Germany: Deutsche Grammophon, 1974, remast.2010, $1 \mathrm{CD}$. . Concertos. Arthur Rubinstein. New York: RCA Victor, 1958, 1 CD.

. Concertos. Guiomar Novaes. New York: Vox Legends, 1960, 2 CDs. . Chopin Chez Pleyel. Alain Planes. Paris: Harmonia Mundi, 2009, 1 CD. . Concertos. Emanuel Ax, Sir Charles Mackerras, Orchestra of the Age of Enlightenment. USA: Sony Classical, 1999, 2 CDs.

Études op.10 \& op.25. Claudio Arrau. USA: EMI Records, 1957, 1 CD. Nocturnes. Arthur Rubinstein. New York: RCA Victor, 1949/1950, 2 CDs. Nocturnes. Claudio Arrau. New York: Philips, 1978, 2 CDs. Sonaten \& Fantasien. Elisabeth Leonskaja: Germany: Teldec, 1989, 1 CD.

Nahim Marun recebeu diversos prêmios por sua carreira artística, entre eles, o Prêmio Melhor Solista do Ano da APCA - Associação Paulista dos Críticos de Arte. Suas gravações no Brasil e Itália receberam o Diapason d'Or, o Prêmio Bravo! de Cultura Melhor CD de Música Erudita de 2006 e foram selecionadas entre as melhores do ano pela Iberian and Latin Music Society de Londres. Concluiu Mestrado em Performance pelo The Mannes College of Music - New School for Social Research de New York com bolsa CAPES, Doutorado em Música pela UNICAMP e Pós-Doutorado pela Université ParisSorbonne (Paris IV) com bolsa FAPESP. Seus principais mentores de piano foram Isabel Mourão no Brasil e Grant Johannesen nos Estados Unidos. Estudou matérias teóricas e composição com Koellreutter no Brasil. Professor efetivo de piano dos cursos de graduação e pós-graduação do Instituto de Artes da UNESP de São Paulo. Publicou os livros Revisão Crítica das Canções de Villa-Lobos, pela Editora Cultura Acadêmica e Técnica Avançada para Pianistas, pela Editora da UNESP. 